\title{
1 A bacteria-based assay to study SARS-CoV-2 protein-protein interactions
}

3 Running title: Bacteria-based SARS-CoV-2 protein interactome

5 Benjamin L. Springstein ${ }^{1 \#}$, Padraig Deighan ${ }^{1}$, Grzegorz Grabe ${ }^{1}$, Ann Hochschild ${ }^{1 \#}$

$7 \quad{ }^{1}$ Department of Microbiology, Harvard Medical School, Boston, MA 02115, USA

10 " Corresponding authors:

11 ahochschild@hms.harvard.edu

12 benjamin_springstein@hms.harvard.edu 


\section{Abstract}

14 Methods for detecting and dissecting the interactions of virally encoded proteins are essential

15 for probing basic viral biology and providing a foundation for therapeutic advances. The dearth

16 of targeted therapeutics for the treatment of COVID-19, an ongoing global health crisis,

17 underscores the importance of gaining a deeper understanding of the interactions of SARS-

18 CoV-2-encoded proteins. Here we describe the use of a convenient bacteria-based two-hybrid

19 (B2H) system to analyze the SARS-CoV-2 proteome. We identify sixteen distinct intraviral

20 protein-protein interactions (PPIs), involving sixteen proteins. We find that many of the identified

21 proteins interact with more than one partner. We further show how our system facilitates the

22 genetic dissection of these interactions, enabling the identification of selectively disruptive

23 mutations. We also describe a modified $\mathrm{B} 2 \mathrm{H}$ system that permits the detection of disulfide bond-

24 dependent PPIs in the normally reducing Escherichia coli cytoplasm and we use this system to 25 detect the interaction of the SARS-CoV-2 spike protein receptor-binding domain (RBD) with its 26 cognate cell surface receptor ACE2. We then examine how the RBD-ACE2 interaction is

27 perturbed by several RBD amino acid substitutions found in currently circulating SARS-CoV-2 28 variants. Our findings illustrate the utility of a genetically tractable bacterial system for probing

29 the interactions of viral proteins and investigating the effects of emerging mutations. In principle,

30 the system could also facilitate the identification of potential therapeutics that disrupt specific

31 interactions of virally encoded proteins. More generally, our findings establish the feasibility of

32 using a $\mathrm{B} 2 \mathrm{H}$ system to detect and dissect disulfide bond-dependent interactions of eukaryotic 33 proteins. 


\section{Importance}

35 Understanding how virally encoded proteins interact with one another is essential in elucidating

36 basic viral biology, providing a foundation for therapeutic discovery. Here we describe the use of

37 a versatile bacteria-based system to investigate the interactions of the protein set encoded by

38 SARS-CoV-2, the virus responsible for the current pandemic. We identify sixteen distinct

39 intraviral protein-protein interactions, involving sixteen proteins, many of which interact with

40 more than one partner. Our system facilitates the genetic dissection of these interactions,

41 enabling the identification of selectively disruptive mutations. We also describe a modified

42 version of our bacteria-based system that permits detection of the interaction between the

43 SARS-CoV-2 spike protein (specifically its receptor binding domain) and its cognate human cell

44 surface receptor ACE2 and we investigate the effects of spike mutations found in currently

45 circulating SARS-CoV-2 variants. Our findings illustrate the general utility of our system for

46 probing the interactions of virally encoded proteins. 


\section{Introduction}

The causative agent of COVID-19, SARS-CoV-2, like SARS-CoV (hereafter SARS-CoV1) and the Middle East respiratory syndrome coronavirus (MERS-CoV), is a zoonotic pathogen

50 that belongs to the genus of $\beta$-coronaviruses [1,2]. A $\sim 30 \mathrm{~kb}$ single stranded (+)-sense RNA

51 virus, SARS-CoV-2 encodes 16 non-structural proteins (Nsp1-Nsp16), which are transcribed

52 from two major open reading frames (ORF1a and ORF1b) and later post-translationally

53 processed by proteases to give rise to the individual Nsps [3]. The main function of the Nsps is

54 to provide and maintain the replication and transcription complex (RTC), promoting viral RNA

55 synthesis by the RNA-dependent RNA polymerase Nsp12 [3]. However, the Nsps have also

56 been implicated in other viral processes such as host innate immune system evasion - for

57 example, by suppressing aspects of the interferon response [4]. The virus also encodes four

58 structural proteins, the membrane $(M)$ protein, the nucleocapsid $(N)$ protein, the envelope $(E)$

59 protein and the spike (S) glycoprotein, and at least six accessory proteins (ORF3a, ORF6,

60 ORF7a, ORF7b, ORF8 and ORF10) [5]. The main function of coronavirus structural proteins is

61 to mediate cell entry, virus particle assembly and release from the host cells by budding, though

62 like the Nsps, structural proteins also participate in immune evasion. By contrast, the accessory

63 proteins are non-conserved and highly variable among different coronavirus species; although

64 their functional roles remain largely unknown, they too have been associated with immune 65 evasion and disease severity [3].

66 Given the ongoing global crisis caused by the SARS-CoV-2 pandemic and the 67 continuing need for targeted therapeutics for the treatment of COVID-19, understanding the 68 intraviral and viral-host protein-protein interactions (PPIs) of SARS-CoV-2 remains a priority. An

69 extensive virus-virus and host-virus PPI study recently highlighted the importance of Nsp10 as a

70 potential inducer of the so-called cytokine storm (a dysregulated and hyperactive immune 71 response) [6], thought to be the main cause for severe disease outcome and death in COVID-19 
72 patients [2]. Li et al. (2021) further identified Nsp8 as a SARS-CoV-2 PPI hub [6], promoting

73 interactions with other Nsps, accessory proteins, and one structural protein. Similar

74 observations were previously also obtained for SARS-CoV-1 Nsp8 [7]. These findings suggest

75 that Nsp8 and Nsp10 might provide particularly efficacious targets for drug development.

The SARS-CoV-2 spike protein, which is present on the viral surface as trimers, consists

77 of two functionally distinct subunits, S1 and S2 [8,9]. The membrane-distal S1 subunit uses its

78 receptor-binding domain $(\mathrm{RBD})$ to initiate the process of viral entry into human host cells by

79 binding to the cell surface protein angiotensin-converting enzyme 2 (ACE2), which also serves

80 as the receptor for SARS-CoV-1 but not for the more distantly related MERS-CoV. Following

81 ACE2 binding, the membrane-localized host cell serine protease TMPRSS2 cleaves the spike

82 protein at a specific site, triggering a series of dramatic conformational changes in the S2

83 subunit, which in turn mediate fusion of the viral and host membranes, enabling viral entry [10].

84 As well as being a critical determinant of viral tropism, the RBD is a major target for SARS-CoV-

85 2-neutralizing antibodies, including those identified from convalescent patient peripheral blood

86 mononuclear cells and those elicited by current (spike-based) vaccines [9,11-18].

Compared with those of other RNA viruses, the mutation rate of SARS-CoV-2 is

88 considered low-moderate $\left(6-9 \times 10^{-4}\right.$ bases/genome/year) [19-21], although others have pointed

89 out that multiple identical mutation hotspot events occurring at different points in time could lead

90 to an underestimation of the overall mutation rate [22]. Nevertheless, the pandemic has given

91 rise to a proliferation of variant lineages, including those designated variants of concern (VOCs)

92 by the World Health Organization (WHO), based on one or more of the following criteria:

93 increase in transmissibility; increase in virulence; decrease in effectiveness of public health

94 measures, diagnostics, therapeutics or vaccines (www.who.int/en/activities/tracking-SARS-CoV-

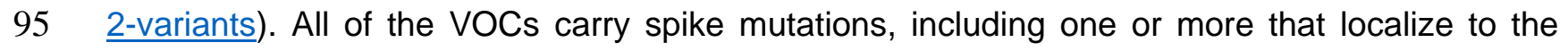


96 RBD, motivating efforts to gain a systematic understanding of the effects of RBD amino acid

97 substitutions on ACE2 binding [23].

99 CoV-2 in a heterologous non-eukaryotic system. Using this system, we describe a bacteria-

100 based intraviral interactome. We further demonstrate the utility of the bacterial system for 101 genetically dissecting the SARS-CoV-2 PPIs by identifying mutations that selectively affect one 102 or another interaction. In addition, we describe a modified $\mathrm{B} 2 \mathrm{H}$ system that allows us to detect 103 disulfide bond-dependent PPIs in the otherwise reducing Escherichia coli cytoplasm. We use 104 this system to detect the spike RBD-ACE2 interaction and to investigate the effects of mutations 105 found in VOCs. Our findings set the stage for further investigations of viral PPIs in a convenient 106 and genetically tractable bacterial system, as well as establishing the feasibility of using our 107 modified system to detect and dissect disulfide bond-dependent PPls of other eukaryotic 108 proteins.

\section{Results}

\section{Bacterial two-hybrid system to detect interactions of SARS-CoV-2 proteome}

112 Previous studies have used yeast two-hybrid $(\mathrm{Y} 2 \mathrm{H})$ systems, a mammalian two-hybrid system

113 and co-immunoprecipitation experiments (co-IPs) to investigate the SARS-CoV-1 and SARS-

114 CoV-2 protein interactomes, identifying overlapping but also distinct interactions depending on

115 the employed system $[6,7,26,27]$. Compared with bacteria, yeast have a relatively slow growth

116 rate and are more difficult to culture and transform for labs that do not routinely work with yeast.

117 To provide a more accessible alternative to $\mathrm{Y} 2 \mathrm{H}$ systems as well as the less commonly used 118 mammalian two-hybrid system, we here describe the successful use of a $\mathrm{B} 2 \mathrm{H}$ system 119 developed in our lab (Fig. 1A) [24,25] to test for viral PPIs. We fused all NCBI-predicted E. coli 
120 codon-optimized SARS-CoV-2 open reading frames (ORFs; listed in Fig. 1B, see also NCBI

121 accession \#: NC_045512.2) to the DNA binding protein $\mathrm{Cl}$ of bacteriophage $\lambda(\lambda \mathrm{Cl})$ and to the

$122 N$-terminal domain of the $\alpha$ subunit ( $\alpha$ NTD) of RNA polymerase (RNAP). We then tested each

123 SARS-CoV-2 ORF for interaction with the other SARS-CoV-2 ORFs and itself. Interaction

124 between two given ORFs ( $\mathrm{X}$ and $\mathrm{Y}$ ), fused to $\alpha \mathrm{NTD}$ and $\lambda \mathrm{Cl}$, respectively, stabilizes the binding

125 of RNAP to the test promoter such that the magnitude of the lacZ reporter gene expression

126 correlates with the strength of the PPI (Fig. 1A).

\section{Identification of the SARS-CoV-2 interactome using a B2H system}

128 Using our B2H system, we initially tested each SARS-CoV-2 ORF against each other SARS-

129 CoV-2 ORF and itself in biological duplicate. Protein pairs with at least a 2-fold activation of lacZ

130 over background in one of the replicates were selected for further analysis. The list of interacting

131 proteins was further refined by performing repeat experiments with three biological replicates for

132 each initially identified potential PPI pair. This resulted in a final list of sixteen interacting SARS-

133 CoV-2 protein pairs, including four self-interactions (Fig. 2). Some of these interactions were

134 identified only with a specific fusion partner combination (i.e., protein $\mathrm{X}$ fused to $\alpha$ NTD and

135 protein $\mathrm{Y}$ fused to $\lambda \mathrm{Cl}$, or the other way around), while others were fusion partner-independent

136 (i.e., interaction between proteins $X$ and $Y$ regardless of their fusion to $\alpha$ NTD or $\lambda C I$ ). Self-

137 interacting proteins (Nsp7, Nsp9, ORF6 and ORF10) were by definition fusion partner-

138 insensitive; however, four other pairs of proteins (Nsp7+Nsp8, Nsp10+Nsp14, Nsp10+Nsp16,

$139 \mathrm{Nsp3+N}$, and Nsp8+ORF6) also interacted detectably regardless of the fusion partner

140 (Supplementary Fig. 1).

$141 \quad$ Among the identified interacting pairs, several particularly strong PPIs were observed,

142 including the Nsp7 self-interaction, Nsp7+Nsp8, Nsp10+Nsp16, N+Nsp3 and Nsp9+Nsp11 (Fig.

143 3). In fact, the Nsp10+Nsp16 pair interacted significantly more strongly than our positive control, 
144 representing one of the strongest interactions we have ever measured with our $\mathrm{B} 2 \mathrm{H}$ assay. For

145 our $\mathrm{B} 2 \mathrm{H}$ assays, we routinely consider an interaction to be reliable when we detect at least a

146 two-fold increase in lacZ reporter gene expression (measured as $\beta$-galactosidase activity) over

147 the background (obtained with the negative controls). Applying this cut-off to our experimental

148 data, we identified several medium-to-weak interactions (2- to 5-fold increase over the negative

149 controls; Supplementary Fig. 2). The interactions of Nsp8+ORF7b and ORF10+ORF10 closely

150 missed the 2-fold cutoff but were nonetheless included in the list because a previous SARS-

151 CoV-2 interactome study also identified those interactions (based on co-IP data) [6].

Comparison of our SARS-CoV-2 B2H data with the previously reported SARS-CoV-2

$153 \mathrm{Y} 2 \mathrm{H}$ and co-IP data [6] revealed four PPIs that were shared among the three assay systems,

154 providing strong support for their biological relevance (Supplementary Fig. 3). These included

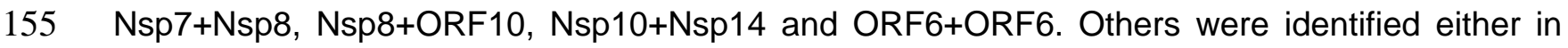

156 only one of the assay systems (i.e., $\mathrm{B} 2 \mathrm{H}, \mathrm{Y} 2 \mathrm{H}$ or co-IP) or in two assay systems (B2H and $\mathrm{Y} 2 \mathrm{H}$,

$157 \mathrm{~B} 2 \mathrm{H}$ and co-IP, or Y2H and co-IP) (Supplementary Fig. 3). Furthermore, some of our identified

158 interactions are validated by co-crystal structures. These included Nsp7+Nsp8 (Protein Data

159 Bank (PDB) accession number 6YHU [28]), Nsp10+Nsp14 (PDB: 5NFY from SARS-CoV-1 [29]

160 or more recently 7DIY from SARS-CoV-2 [30]), Nsp10+Nsp16 (PDB: 6W4H [31]) and the Nsp9

161 self-interaction (PDB: 6W9Q [32]). Notably, no self-interaction of Nsp9 was identified in a

162 previous $\mathrm{Y} 2 \mathrm{H}$ and co-IP analysis of the SARS-CoV-2 interactome [6], highlighting the

163 importance of employing several different interaction assays when studying the interactome of a

164 given protein set to avoid loss of information due to experimental system idiosyncrasies.

165 Similar to previous observations for SARS-CoV-1 [7], we identified Nsp8 as a major

166 SARS-CoV-2 interaction hub, interacting with six other SARS-CoV-2 ORFs (Fig. 3,

167 Supplementary Fig. 2), consistent with a critical role for Nsp8 in SARS coronavirus biology.

168 Nonetheless, most of the interaction partners we identified for Nsp8 in SARS-CoV-2 are 
different than those identified previously for SARS-CoV-1 [7,26,27] (Supplementary Fig. 4).

170 Overall, only six PPIs were identified in our SARS-CoV-2 B2H analysis and at least one of three

171 independent SARS-CoV-1 Y2H studies, including two involving Nsp8 (Supplementary Fig. 4).

172 Notably, there are considerable differences between the results of the three previous $\mathrm{Y} 2 \mathrm{H}$

173 studies [7,26,27] and only three PPIs (Nsp8+Nsp7, Nsp10+Nsp14, and Nsp10+Nsp16) were

174 independently identified in two SARS-CoV-1 two-hybrid assays and our SARS-CoV-2 B2H

175 assay (Supplementary Fig. 4). This could reflect significant differences between the PPI

176 networks in SARS-CoV-1 and SARS-CoV-2 and/or differences in the assays themselves

177 (procedures and background organism).

178 Targeted mutational screens identify interaction partner-specific sites of protein-protein 179 interaction in CoV-2 proteins with more than one interaction partner

180 As a genetic assay, the $\mathrm{B} 2 \mathrm{H}$ system facilitates the dissection of specific PPIs through both

181 targeted and random mutagenesis. Having established the utility of the $\mathrm{B} 2 \mathrm{H}$ assay in testing for

182 viral PPIs, we next sought to use this assay to dissect the interactions of selected viral proteins

183 through targeted mutational analysis. Specifically, we chose proteins that interacted with more

184 than one partner and sought to disrupt the interaction of such a protein with one of its partners

185 while preserving its interaction with another. We initially selected Nsp10 with two known

186 interaction partners, Nsp14 and Nsp16, and attempted to disrupt only its interaction with Nsp14.

187 To identify suitable targets for mutagenesis, we analyzed the crystal structures of Nsp10-Nsp14

188 (PDB ID: 5NFY [29]) and Nsp10-Nsp16 (PDB ID: 6W4H [31]) and their protein-protein interfaces

189 using PDBePISA [33]. Based on this approach, we selected three sets of amino acid

190 substitutions likely to affect the binding of Nsp10 to Nsp14, while leaving its interaction with

191 Nsp16 intact (assuming that the substitutions do not result in allosteric effects). While the Nsp10

$192 \mathrm{~F} 16 \mathrm{~A} / \mathrm{F} 19 \mathrm{~A} / \mathrm{V} 21 \mathrm{~A}$ set targeted the hydrophobic region, the Nsp10 T5A/T12A/S15A and

193 S29A/S33A sets partially disrupted the hydrogen bond network of the Nsp10-Nsp14 interface 
194 (Fig. 4A,C). Each of the three multiply substituted Nsp10 mutants lost the ability to interact 195 detectably with Nsp14 while maintaining an approximately wild-type interaction with Nsp16 (Fig. 196 4B). We note that the close approach of amino acid side chains at a protein-protein interface as 197 revealed by X-ray crystallography does not necessarily indicate that they participate in a 198 functionally important interaction. However, the loss of a detectable interaction between each of 199 the three Nsp10 mutants and Nsp14 in our B2H assay suggests that at least a subset of the 200 selected residues make stabilizing contacts. Furthermore, although the Nsp10-Nsp16 201 interaction serves as a control, we also confirmed that the introduced amino acid substitutions 202 were not generally destabilizing (Supplementary Fig. 5).

We then focused on Nsp16 with two interaction partners, Nsp10 and Nsp15, targeting 204 the Nsp16-Nsp10 pair, which displayed a significantly higher B2H signal than that of the Nsp16205 Nsp15 pair. Here we also utilized the available crystal structure for the Nsp16-Nsp10 complex; 206 however, as there is no structure for the Nsp16-Nsp15 complex, the substitutions introduced 207 into Nsp16 were based solely on their predicted effects on its interaction with Nsp10. 208 Endeavoring to disrupt the Nsp16-Nsp10 interaction, we created two Nsp16 triple substitution 209 mutants, targeting hydrophobic (I40A/M41A/V44A) or hydrophilic (K76A/Q87A/D106A) contacts, 210 and a mutant with the six substitutions combined (Fig. 4C). The data reveal drastic effects of 211 these substitutions on the binding of Nsp16 to Nsp10, resulting in near background or 212 background levels of reporter gene expression for each of the mutants (Fig. 4D). The effects of 213 the same substitutions on the binding of Nsp16 to Nsp15 were modest and not statistically 214 significant. Notably, even though Nsp16 interacts much more weakly with Nsp15 than with 215 Nsp10, reporter gene expression was lower for each of the Nsp16 mutants in combination with 216 Nsp10 than when tested in combination with Nsp15 (Fig. 4D). We also confirmed that these 217 effects are not the result of altered protein levels (Supplementary Fig. 6). Together, these data 
218 illustrate a proof-of-principle approach that can be used to obtain functionally informative

219 mutants within a PPI network.

The $\mathrm{B} 2 \mathrm{H}$ system as a tool to study circulating spike variants and their binding to ACE2

221 To further assess whether our $\mathrm{B} 2 \mathrm{H}$ system can facilitate the study of emerging mutational 222 changes in viral populations, we next asked whether we could use our system to study the 223 interaction between the SARS-CoV-2 spike protein and ACE2. For this, we obtained an E. coli 224 codon-optimized gene fragment encoding the human ACE2 peptidase domain (aa 19-615, 225 hereafter ACE2). We inserted this gene fragment and a set of gene fragments encoding multiple 226 domains of the spike protein (including the RBD, aa 331-521) into our two-hybrid vectors, fusing

227 ACE2 and each of the spike domains to both $\lambda \mathrm{Cl}$ and $\alpha \mathrm{NTD}$. Initial experiments using our 228 standard E. coli B2H strain (FW102 OL2-62 termed B2H; Supplementary Table 1A) failed to 229 reveal an interaction of ACE2 with any of the selected spike domains (Supplementary Fig. 7; 230 data not shown). However, previous studies demonstrated that proper disulfide bond formation 231 is essential in order for spike and ACE2 to engage in a direct interaction [34,35]. Because the $E$. 232 coli cytoplasm is a reducing environment [36], we considered the possibility that the failure to 233 detect a spike-ACE2 interaction with our standard $\mathrm{B} 2 \mathrm{H}$ strain might be due to a lack of proper 234 disulfide bond formation. To circumvent this obstacle, we modified a commercially available $E$. 235 coli strain (SHuffle from NEB, MA, USA) that permits the efficient expression and formation of 236 active full-length antibodies in the E. coli cytoplasm [37], adapting it for use with our two-hybrid 237 system (Methods). The SHuffle strain is deleted for two genes that encode cytoplasmic 238 reductases (trxB and gor) and also harbors the normally periplasmic disulfide bond isomerase 239 DsbC in the cytoplasm [38,39]. With this modified oxidizing strain (termed BLS148; 240 Supplementary Table 1A), we were able to detect an interaction of the spike RBD with ACE2 241 (Fig. 5A,B). Moreover, this interaction was abrogated when we mutated a pair of cysteine 242 residues (replacing them individually and in combination with serine residues) that engage in 
243 disulfide bond formation within the RBD (C379 and C432) [34], consistent with the surmise that

244 the oxidizing strain permits detection of the RBD-ACE2 interaction by enabling appropriate 245 disulfide bond formation and correct folding of the interacting partners (Fig. 5B; Supplementary 246 Fig. 8).

Having adapted our B2H system for the study of disulfide bond-dependent PPIs, we sought to test different spike (RBD) circulating variants for their abilities to bind ACE2. The RBD amino acid substitutions included in our study are found in several SARS-CoV-2 variants that were previously designated VOCs by the Centers for Disease Control and Prevention (USA;

251 https://www.cdc.gov/coronavirus/2019-ncov/variants/variant-info.html, initially accessed

252 05/30/2021). Specifically, we included the Alpha variant (B.1.1.7, first identified in the United 253 Kingdom) that carries the RBD N501Y substitution, the Beta variant (B.1.351, first identified in 254 South Africa) that carries the RBD K417N, E484K and N501Y substitutions, as well as the 255 Epsilon variant (B.1.429, first identified in California) that carries the RBD L452R substitution, 256 introducing the corresponding mutations into the spike RBD on our B2H vector (Fig. 5D). The 257 latter two variants have recently gained more attention as they are considered immune escape 258 variants, potentially resulting in a partial loss of immunity in previously infected or immunized 259 people [40-47]. In contrast, the Alpha variant is not characterized by a marked escape from 260 antibody neutralization [41,42,45-47]. Factors that are believed to contribute, potentially, to 261 immune escape include changes in the spike protein that: (i) enhance or stabilize its binding to 262 ACE2 or (ii) decrease the binding of specific anti-spike neutralizing antibodies [48-50].

264 included RBD mutants bearing component single and double substitutions from the Beta variant 265 (Fig. 5C; Supplementary Fig. 9). We found that the N501Y substitution (in the context of the 266 Alpha variant) had no observable effect on ACE2 binding. In contrast, the L452R substitution 267 (Epsilon variant) resulted in a statistically significant increase in ACE2 binding. Substitutions 
K417N, E484K and N501Y (Beta variant) together resulted in a significant reduction in ACE2 binding, as did the individual component substitutions $\mathrm{K} 417 \mathrm{~N}$ and $\mathrm{E} 484 \mathrm{~K}$ (with the E484K

270 substitution having the stronger effect). However, the effects of these two substitutions were

271 partially (E484K) or fully (K417N) abrogated when combined with the N501Y substitution. The

272 binding of the triply substituted variant was indistinguishable from that of the E484K/N501Y

273 double mutant, indicating that in this context the $\mathrm{K} 417 \mathrm{~N}$ substitution neither weakens or

274 strengthens the interaction. Together, these findings indicate that our modified B2H system

275 enables detection of disulfide bond-dependent PPIs and can be used to investigate the effects

276 of RBD variant substitutions on the RBD-ACE2 interaction.

\section{Discussion}

Use of bacteria-based assay to investigate SARS-CoV-2 interactome

Here we use a versatile bacteria-based genetic tool for detecting and dissecting PPIs

$[24,25]$ to screen the SARS-CoV-2 proteome for intraviral PPIs. We detected a total of sixteen

282 PPIs, including four self-interactions. Nine of these interactions were also detected in a previous

283 SARS-CoV-2 PPI study (Supplementary Fig. 3), as assessed by Y2H-based screens and/or

284 mammalian cell-based co-IP experiments [6]. Additionally, four of the interactions we detected

285 have been captured in co-crystal structures, including the Nsp9 self-interaction (PDB: 6W9Q;

286 [32]), which was not identified by either $\mathrm{Y} 2 \mathrm{H}$ or co-IP analyses [6]. Of the six interactions we

287 detected that were not previously described in the context of SARS-CoV-2, three were

288 previously detected by $\mathrm{Y} 2 \mathrm{H}$ analyses in the context of SARS CoV-1 (Supplementary Fig. 4). Of

289 the remaining three interactions, not previously described, two $(\mathrm{Nsp} 9+\mathrm{Nsp} 11$ and $\mathrm{Nsp} 3+\mathrm{N})$ were

290 particularly strong as assessed in our B2H assay (Fig. 3). 
Although the different assays that have been used to characterize the SARS-CoV-2

292 interactome have provided results that often corroborate one another, there are many examples

293 of interactions that have been detected with only one of the assays. These discrepancies

294 highlight the importance of employing multiple assay systems, each with its own inherent

295 limitations, to maximize the likelihood of obtaining a complete picture. Because of its

296 experimental accessibility, we expect that our B2H assay will be useful in evaluating other viral

297 proteomes, particularly by taking advantage of our oxidizing reporter strain that better

298 approximates the eukaryotic cell environment in allowing for proper disulfide bond formation in

299 the E. coli cytoplasm [51,52]. To further extend the spectrum of testable viral and eukaryotic

300 PPIs, the system could be augmented to enable the detection of phosphorylation-dependent

301 PPIs by introducing specific mammalian kinases into our reporter stain [53]. Given that many

302 mammalian (and presumably viral) proteins are constitutively phosphorylated in yeast [54-56], a

303 lack of properly phosphorylated proteins in our B2H system could explain, at least in principle,

304 why some SARS-CoV-2 PPIs were identified only in the Y2H screens [6] and not in our system

305 (Supplementary Fig. 3). We note, however, that a comprehensive phosphoproteomics analysis

306 of SARS-CoV-2-infected cells [57] suggests that other than interactions involving the N protein,

307 which was found to be phosphorylated at multiple sites, most of the viral PPls that were

308 detected by $\mathrm{Y} 2 \mathrm{H}$ analysis but not in our $\mathrm{B} 2 \mathrm{H}$ system involve proteins that were not detectably

309 phosphorylated.

\section{Genetic dissection of specific SARS-CoV-2 PPIs}

A benefit of two-hybrid approaches for studying PPIs is that detected interactions can be

312 readily dissected genetically, something that is particularly straightforward to do with our $\mathrm{B} 2 \mathrm{H}$

313 system. As a proof-of-principle, we used a structure-based approach to investigate the effects of

314 targeted mutations on specific SARS-CoV-2 PPIs, identifying substitutions that disrupt one

315 interaction but not another. In addition to facilitating the evaluation of specific circulating or 
316 targeted mutations, our $\mathrm{B} 2 \mathrm{H}$ system can readily be adapted to screen for randomly generated

317 mutations that selectively affect one PPI and not another [58] when there is insufficient

318 information to make informed predictions from structural or other data. The identification of such

319 mutations could facilitate the functional analysis of particular PPIs and inform the choice of

320 potential drug targets for small molecule drug design. Furthermore, with a suitably modified

321 reporter strain to improve compound accessibility [59], compound or peptide libraries could be

322 screened to identify candidates that might target specific SARS-CoV-2 PPIs. It should also be

323 feasible to adapt our B2H reporter system for an in vitro cell-free protein expression system,

324 thereby facilitating compound screenings.

\section{Use of oxidizing B2H reporter strain enables detection of RBD-ACE2 interaction}

Based on previous studies, we anticipated a high-affinity interaction between the spike

327 RBD and ACE2 [9,23,34]. With our modified bacteria-based system, we found that the RBD-

328 ACE2 interaction resulted in a roughly 3-fold increase in lacZ reporter gene expression over

329 background, a relatively modest effect. One possible explanation is that the $\lambda \mathrm{Cl}$-ACE2 fusion

330 protein is produced at relatively low levels compared with unfused $\lambda \mathrm{Cl}$ and other $\lambda \mathrm{Cl}$ fusion

331 proteins we have studied in the past (Supplementary Fig. 8), perhaps resulting in intracellular

332 concentrations insufficient to saturate the DNA-binding site on our lacZ reporter. Another

333 possible explanation (not mutually exclusive) lies in the fact that both the SARS-CoV-2 spike

334 protein and ACE2 are glycosylated in mammalian cells [9,60], with some studies suggesting that

335 glycan-side chain interactions may be important in stabilizing the RBD-ACE2 interaction [61,62].

336 Thus, the interaction detected in our B2H system could be compromised by the lack of

337 mammalian-like $\mathrm{N}$ - and O-glycosylation in E. coli [63].

338 Our B2H system enabled us to assess the effects of specific RBD amino acid 339 substitutions that have been identified in globally circulating SARS-CoV-2 variants. We focused 
340 specifically on three VOCs, as designated by the CDC at the time we initiated our study: the

341 Alpha variant (B.1.1.7), the Beta variant (B.1.351) and the Epsilon variant (B.1.429), carrying

342 RBD substitutions N501Y, N501Y/K417N/E484K, and L452R, respectively (see Fig. 5D) [41].

343 We note that as of September 21, 2021 each of these variants has been deescalated from a

344 VOC to a variant being monitored (VBM) by the CDC. We also note that the highly contagious

345 and rapidly proliferating Delta variant, currently designated as a VOC, harbors the L452R

346 substitution in the RBD, together with a second substitution (T478K) [64].

Mutated in both the Alpha and the Beta variants, residue N501 is localized at the binding

348 interface with ACE2 [34,65] and many reports have suggested that the N501Y substitution

349 increases the affinity of the RBD for ACE2 [23,48,66-70] (but see [71] for a discrepant

350 prediction), potentially explaining the elevated infectivity of the Alpha variant. In a study in which

351 the effects of all possible RBD amino acid substitutions were examined using a yeast-surface-

352 display platform, Starr et al. identified N501Y as one of the substitutions causing the highest

353 gain in ACE2-binding affinity [23]. In contrast, our B2H assay did not reveal any significant effect

354 of the N501Y substitution on the strength of the RBD-ACE2 interaction. Possibly this

355 discrepancy is due to the lack of glycosylation in the bacterial system; in fact, an ACE2 glycan

356 (N322) that has been reported to enhance RBD-ACE2 binding is part of the same binding patch

357 that includes N501 [62]. Nonetheless, we did observe a binding enhancing, compensatory effect

358 of the N501Y substitution when tested in the context of the Beta variant. That is, we found that

359 Beta-associated substitutions $\mathrm{K} 417 \mathrm{~N}$ and E484K both reduced ACE2 binding when tested

360 individually, and that the N501Y substitution compensated for these effects, partially in the case

361 of E484K and fully in the case of K417N. Our results thus suggest that substitutions $\mathrm{K} 417 \mathrm{~N}$ and

362 E484K, which have been implicated in significant immune escape [43-45,72-74], may impose a

363 cost on ACE2 binding that is compensated by the N501Y substitution (see also [70]). Consistent

364 with our findings, the K417N substitution has been previously reported to weaken ACE2 binding 
$365[72,75,76]$; however, in contrast with our results, Starr et al. [23] found that the E484K 366 substitution had a small positive effect on ACE2 binding.

In the case of the L452R substitution, which is present in the Epsilon variant and also in

368 the Delta variant [64], we observed a modest enhancement of ACE2 binding. Residue L452 is

369 positioned at the edge of the binding interface with ACE2 and although this residue does not

370 make direct contact with ACE2 [34,77], evidence suggests that substitution L452R enhances

371 viral infectivity significantly [77,78]. Furthermore, it has been suggested that the L452R mutation

372 is responsible for the dramatic clonal expansion of lineages carrying this mutation [79], possibly

373 due to a decrease in the potency of antibody neutralization or through other immune escape

374 characteristics $[44,46,64,77,78,80]$. Whether or not an effect of the L452R substitution on ACE2

375 binding, apparently modest, is a contributing factor in the rapid spread of variants carrying this

376 mutation remains to be determined.

\section{Summary}

378 Taken together, our results illustrate the utility of a $\mathrm{B} 2 \mathrm{H}$ system as an accessible and 379 economical genetic tool to complement other methods for studying viral PPIs. To the best of our 380 knowledge, we provide the first bacteria-based viral interactome, describing sixteen different 381 intraviral PPIs from SARS-CoV-2. As a non-eukaryotic system, the B2H assay is unlikely to 382 contain bridging factors that can complicate the interpretation of positive results. At the same 383 time, the bacterial system lacks the machinery for enabling potentially relevant post-translational 384 modifications such as protein phosphorylation (which could however be engineered into the 385 system; [53]) and protein glycosylation. Although generally a limitation, the lack of protein 386 glycosylation could in certain situations be informative, enabling a comparison between systems 387 that do and do not support this modification. The new oxidizing $\mathrm{B} 2 \mathrm{H}$ reporter strain that we 388 describe enabled us to detect the SARS-CoV-2 spike RBD-ACE2 interaction and characterize 
389 the effects of several RBD substitutions present in circulating variants. This strain provides a

390 means to test newly arising coronavirus lineages for binding to ACE2 or other human cell

391 surface receptors in the future, as well as extending the reach of the $\mathrm{B} 2 \mathrm{H}$ system to include

392 disulfide bond-dependent PPIs in general. 


\section{References}

394

1 Zhou P, Yang X Lou, Wang XG, Hu B, Zhang L, Zhang W, Si HR, Zhu Y, Li B, Huang CL, Chen HD, Chen J, Luo Y, Guo H, Jiang R Di, Liu MQ, Chen Y, Shen XR, Wang X, Zheng XS, Zhao K, Chen QJ, Deng F, Liu LL, Yan B, Zhan FX, Wang YY, Xiao GF \& Shi ZL (2020) A pneumonia outbreak associated with a new coronavirus of probable bat origin. Nature 579, 270-273.

$2 \mathrm{Hu}$ B, Guo H, Zhou P \& Shi ZL (2021) Characteristics of SARS-CoV-2 and COVID-19. Nat Rev Microbiol 19, 141-154.

3 V'kovski P, Kratzel A, Steiner S, Stalder H \& Thiel V (2021) Coronavirus biology and replication: implications for SARS-CoV-2. Nat Rev Microbiol 19, 155-170.

4 Park A \& Iwasaki A (2020) Type I and Type III Interferons - Induction, Signaling, Evasion, and Application to Combat COVID-19. Cell Host Microbe 27, 870-878.

5 Wu F, Zhao S, Yu B, Chen YM, Wang W, Song ZG, Hu Y, Tao ZW, Tian JH, Pei YY, Yuan ML, Zhang YL, Dai FH, Liu Y, Wang QM, Zheng JJ, Xu L, Holmes EC \& Zhang YZ (2020) A new coronavirus associated with human respiratory disease in China. Nature 579, 265269.

6 Li J, Guo M, Tian X, Wang X, Yang X, Wu P, Liu C, Xiao Z, Qu Y, Yin Y, Wang C, Zhang Y, Zhu Z, Liu Z, Peng C, Zhu T \& Liang Q (2021) Virus-Host Interactome and Proteomic Survey Reveal Potential Virulence Factors Influencing SARS-CoV-2 Pathogenesis. Med 2, 99-112.e7.

7 von Brunn A, Teepe C, Simpson JC, Pepperkok R, Friedel CC, Zimmer R, Roberts R, Baric R \& Haas J (2007) Analysis of intraviral protein-protein interactions of the SARS coronavirus ORFeome. PLoS One 2, e459.

8 Wrapp D, Wang N, Corbett KS, Goldsmith JA, Hsieh CL, Abiona O, Graham BS \& McLellan JS (2020) Cryo-EM structure of the 2019-nCoV spike in the prefusion conformation. Science 367, 1260-1263.

9 Walls AC, Park YJ, Tortorici MA, Wall A, McGuire AT \& Veesler D (2020) Structure, Function, and Antigenicity of the SARS-CoV-2 Spike Glycoprotein. Cell 181, 281-292.e6.

10 Hoffmann M, Kleine-Weber H, Schroeder S, Krüger N, Herrler T, Erichsen S, Schiergens TS, Herrler G, Wu NH, Nitsche A, Müller MA, Drosten C \& Pöhlmann S (2020) SARS-CoV-2 Cell Entry Depends on ACE2 and TMPRSS2 and Is Blocked by a Clinically Proven Protease Inhibitor. Cell 181, 271-280.e8.

11 Premkumar L, Segovia-Chumbez B, Jadi R, Martinez DR, Raut R, Markmann AJ, Cornaby C, Bartelt L, Weiss S, Park Y, Edwards CE, Weimer E, Scherer EM, Rouphael N, Edupuganti S, Weiskopf D, Tse L V., Hou YJ, Margolis D, Sette A, Collins MH, Schmitz J, Baric RS \& de Silva AM (2020) The receptor-binding domain of the viral spike protein is an immunodominant and highly specific target of antibodies in SARS-CoV-2 patients. Sci Immunol 5, 1-15.

12 Barnes CO, Jette CA, Abernathy ME, Dam K-MA, Esswein SR, Gristick HB, Malyutin AG, Sharaf NG, Huey-Tubman KE, Lee YE, Robbiani DF, Nussenzweig MC, West AP \& 
Bjorkman PJ (2020) SARS-CoV-2 neutralizing antibody structures inform therapeutic strategies. Nature 588, 682-687.

13 Liu L, Wang P, Nair MS, Yu J, Rapp M, Wang Q, Luo Y, Chan JFW, Sahi V, Figueroa A, Guo X V., Cerutti G, Bimela J, Gorman J, Zhou T, Chen Z, Yuen KY, Kwong PD, Sodroski JG, Yin MT, Sheng Z, Huang Y, Shapiro L \& Ho DD (2020) Potent neutralizing antibodies against multiple epitopes on SARS-CoV-2 spike. Nature 584, 450-456.

14 Barnes CO, West AP, Huey-Tubman KE, Hoffmann MAG, Sharaf NG, Hoffman PR, Koranda N, Gristick HB, Gaebler C, Muecksch F, Cetrulo Lorenzi JC, Finkin S, Hägglöf T, Hurley A, Millard KG, Weisblum Y, Schmidt F, Hatziioannou T, Bieniasz PD, Caskey M, Robbiani DF, Nussenzweig MC \& Bjorkman PJ (2020) Structures of human antibodies bound to SARSCoV-2 spike reveal common epitopes and recurrent features of antibodies. Cell 182, 828842.e16.

15 Pinto D, Park YJ, Beltramello M, Walls AC, Tortorici MA, Bianchi S, Jaconi S, Culap K, Zatta F, De Marco A, Peter A, Guarino B, Spreafico R, Cameroni E, Case JB, Chen RE, Havenar-Daughton C, Snell G, Telenti A, Virgin HW, Lanzavecchia A, Diamond MS, Fink K, Veesler D \& Corti D (2020) Cross-neutralization of SARS-CoV-2 by a human monoclonal SARS-CoV antibody. Nature 583, 290-295.

16 Robbiani DF, Gaebler C, Muecksch F, Lorenzi JCC, Wang Z, Cho A, Agudelo M, Barnes CO, Gazumyan A, Finkin S, Hägglöf T, Oliveira TY, Viant C, Hurley A, Hoffmann HH, Millard KG, Kost RG, Cipolla M, Gordon K, Bianchini F, Chen ST, Ramos V, Patel R, Dizon J, Shimeliovich I, Mendoza P, Hartweger H, Nogueira L, Pack M, Horowitz J, Schmidt F, Weisblum Y, Michailidis E, Ashbrook AW, Waltari E, Pak JE, Huey-Tubman KE, Koranda N, Hoffman PR, West AP, Rice CM, Hatziioannou T, Bjorkman PJ, Bieniasz PD, Caskey M \& Nussenzweig MC (2020) Convergent antibody responses to SARS-CoV-2 in convalescent individuals. Nature 584, 437-442.

17 Zost SJ, Gilchuk P, Case JB, Binshtein E, Chen RE, Nkolola JP, Schäfer A, Reidy JX, Trivette A, Nargi RS, Sutton RE, Suryadevara N, Martinez DR, Williamson LE, Chen EC, Jones T, Day S, Myers L, Hassan AO, Kafai NM, Winkler ES, Fox JM, Shrihari S, Mueller BK, Meiler J, Chandrashekar A, Mercado NB, Steinhardt JJ, Ren K, Loo Y-M, Kallewaard NL, McCune BT, Keeler SP, Holtzman MJ, Barouch DH, Gralinski LE, Baric RS, Thackray LB, Diamond MS, Carnahan RH \& Crowe JE (2020) Potently neutralizing and protective human antibodies against SARS-CoV-2. Nature 584, 443-449.

18 Rogers TF, Zhao F, Huang D, Beutler N, Burns A, He W, Limbo O, Smith C, Song G, Woehl J, Yang L, Abbott RK, Callaghan S, Garcia E, Hurtado J, Parren M, Peng L, Ramirez S, Ricketts J, Ricciardi MJ, Rawlings SA, Wu NC, Yuan M, Smith DM, Nemazee D, Teijaro JR, Voss JE, Wilson IA, Andrabi R, Briney B, Landais E, Sok D, Jardine JG \& Burton DR (2020) Isolation of potent SARS-CoV-2 neutralizing antibodies and protection from disease in a small animal model. Science 369, 956-963.

19 van Dorp L, Acman M, Richard D, Shaw LP, Ford CE, Ormond L, Owen CJ, Pang J, Tan CCS, Boshier FAT, Ortiz AT \& Balloux F (2020) Emergence of genomic diversity and recurrent mutations in SARS-CoV-2. Infect Genet Evol 83, 104351.

20 Singh D \& Yi S V (2021) On the origin and evolution of SARS-CoV-2. Exp Mol Med 53, 537547.

21 van Dorp L, Richard D, Tan CCS, Shaw LP, Acman M \& Balloux F (2020) No evidence for 
increased transmissibility from recurrent mutations in SARS-CoV-2. Nat Commun 11, 5986.

22 De Maio N, Walker CR, Turakhia Y, Lanfear R, Corbett-Detig R \& Goldman N (2021) Mutation Rates and Selection on Synonymous Mutations in SARS-CoV-2. Genome Biol Evol 13, 1-14.

23 Starr TN, Greaney AJ, Hilton SK, Ellis D, Crawford KHD, Dingens AS, Navarro MJ, Bowen JE, Tortorici MA, Walls AC, King NP, Veesler D \& Bloom JD (2020) Deep Mutational Scanning of SARS-CoV-2 Receptor Binding Domain Reveals Constraints on Folding and ACE2 Binding. Cell 182, 1295-1310.e20.

24 Dove SL \& Hochschild A (2004) A Bacterial Two-Hybrid System Based on Transcription Activation. In Protein-Protein Interactions. Methods and Applications (Fu H, ed), pp. 231246. Humana Press, Totowa, NJ.

25 Dove SL, Joung JK \& Hochschild A (1997) Activation of prokaryotic transcription through arbitrary protein-protein contacts. Nature $386,627-630$.

26 Pan J, Peng X, Gao Y, Li Z, Lu X, Chen Y, Ishaq M, Liu D, DeDiego ML, Enjuanes L \& Guo $D$ (2008) Genome-wide analysis of protein-protein interactions and involvement of viral proteins in SARS-CoV replication. PLoS One 3, e3299.

27 Imbert I, Snijder EJ, Dimitrova M, Guillemot JC, Lécine P \& Canard B (2008) The SARSCoronavirus PLnc domain of $\mathrm{nsp} 3$ as a replication/transcription scaffolding protein. Virus Res 133, 136-148.

28 Konkolova E, Klima M, Nencka R \& Boura E (2020) Structural analysis of the putative SARSCoV-2 primase complex. J Struct Bio/ 211, 107548.

29 Ferron F, Subissi L, Silveira De Morais AT, Le NTT, Sevajol M, Gluais L, Decroly E, Vonrhein C, Bricogne G, Canard B \& Imbert I (2018) Structural and molecular basis of mismatch correction and ribavirin excision from coronavirus RNA. Proc Natl Acad Sci 115, E162-E171.

30 Lin S, Chen H, Chen Z, Yang F, Ye F, Zheng Y, Yang J, Lin X, Sun H, Wang L, Wen A, Dong H, Xiao Q, Deng D, Cao Y \& Lu G (2021) Crystal structure of SARS-CoV-2 nsp10 bound to nsp14-ExoN domain reveals an exoribonuclease with both structural and functional integrity. Nucleic Acids Res 49, 5382-5392.

31 Rosas-Lemus M, Minasov G, Shuvalova L, Inniss NL, Kiryukhina O, Brunzelle J \& Satchell KJF (2020) High-resolution structures of the SARS-CoV-2 2'-O-methyltransferase reveal strategies for structure-based inhibitor design. Sci Signal 13, eabe1202.

32 Littler DR, Gully BS, Colson RN \& Rossjohn J (2020) Crystal structure of the SARS-CoV-2 non-structural protein 9, Nsp9. iScience 23, 101258.

33 Krissinel E \& Henrick K (2007) Inference of Macromolecular Assemblies from Crystalline State. J Mol Biol 372, 774-797.

34 Lan J, Ge J, Yu J, Shan S, Zhou H, Fan S, Zhang Q, Shi X, Wang Q, Zhang L \& Wang X (2020) Structure of the SARS-CoV-2 spike receptor-binding domain bound to the ACE2 receptor. Nature 581, 215-220. 
35 Hati S \& Bhattacharyya S (2020) Impact of Thiol-Disulfide Balance on the Binding of Covid19 Spike Protein with Angiotensin-Converting Enzyme 2 Receptor. ACS Omega 5, 1629216298.

36 Stewart EJ, Åslund F \& Beckwith J (1998) Disulfide bond formation in the Escherichia coli cytoplasm: An in vivo role reversal for the thioredoxins. EMBO J 17, 5543-5550.

37 Robinson MP, Ke N, Lobstein J, Peterson C, Szkodny A, Mansell TJ, Tuckey C, Riggs PD, Colussi PA, Noren CJ, Taron CH, Delisa MP \& Berkmen M (2015) Efficient expression of full-length antibodies in the cytoplasm of engineered bacteria. Nat Commun 6, 8072.

38 Bessette PH, Åslund F, Beckwith J \& Georgiou G (1999) Efficient folding of proteins with multiple disulfide bonds in the Escherichia coli cytoplasm. Proc Natl Acad Sci U S A 96, 13703-13708.

39 Lobstein J, Emrich CA, Jeans C, Faulkner M, Riggs P \& Berkmen M (2012) SHuffle, a novel Escherichia coli protein expression strain capable of correctly folding disulfide bonded proteins in its cytoplasm. Microb Cell Fact 11, 753.

40 Stamatatos L, Czartoski J, Wan Y-H, Homad LJ, Rubin V, Glantz H, Neradilek M, Seydoux E, Jennewein MF, MacCamy AJ, Feng J, Mize G, De Rosa SC, Finzi A, Lemos MP, Cohen KW, Moodie Z, McElrath MJ \& McGuire AT (2021) mRNA vaccination boosts cross-variant neutralizing antibodies elicited by SARS-CoV-2 infection. Science 372, 1413-1418.

41 Starr TN, Greaney AJ, Dingens AS \& Bloom JD (2021) Complete map of SARS-CoV-2 RBD mutations that escape the monoclonal antibody LY-CoV555 and its cocktail with LYCoV016. Cell Reports Med 2, 100255.

42 Planas D, Bruel T, Grzelak L, Guivel-Benhassine F, Staropoli I, Porrot F, Planchais C, Buchrieser J, Rajah MM, Bishop E, Albert M, Donati F, Prot M, Behillii S, Enouf V, Maquart M, Smati-Lafarge M, Varon E, Schortgen F, Yahyaoui L, Gonzalez M, De Sèze J, Péré H, Veyer D, Sève A, Simon-Lorière E, Fafi-Kremer S, Stefic K, Mouquet H, Hocqueloux L, van der Werf S, Prazuck T \& Schwartz O (2021) Sensitivity of infectious SARS-CoV-2 B.1.1.7 and B.1.351 variants to neutralizing antibodies. Nat Med 27, 917-924.

43 Liu Z, VanBlargan LA, Bloyet LM, Rothlauf PW, Chen RE, Stumpf S, Zhao H, Errico JM, Theel ES, Liebeskind MJ, Alford B, Buchser WJ, Ellebedy AH, Fremont DH, Diamond MS \& Whelan SPJ (2021) Identification of SARS-CoV-2 spike mutations that attenuate monoclonal and serum antibody neutralization. Cell Host Microbe 29, 477-488.e4.

44 Greaney AJ, Starr TN, Barnes CO, Weisblum Y, Schmidt F, Caskey M, Gaebler C, Cho A, Agudelo M, Finkin S, Wang Z, Poston D, Muecksch F, Hatziioannou T, Bieniasz PD, Robbiani DF, Nussenzweig MC, Bjorkman PJ \& Bloom JD (2021) Mapping mutations to the SARS-CoV-2 RBD that escape binding by different classes of antibodies. Nat Commun 12, 4196.

45 Wang P, Nair MS, Liu L, Iketani S, Luo Y, Guo Y, Wang M, Yu J, Zhang B, Kwong PD, Graham BS, Mascola JR, Chang JY, Yin MT, Sobieszczyk M, Kyratsous CA, Shapiro L, Sheng Z, Huang Y \& Ho DD (2021) Antibody resistance of SARS-CoV-2 variants B.1.351 and B.1.1.7. Nature 593, 130-135.

46 McCallum M, Bassi J, Marco A De, Chen A, Walls AC, lulio J Di, Tortorici MA, Navarro M-J, Silacci-Fregni C, Saliba C, Agostini M, Pinto D, Culap K, Bianchi S, Jaconi S, Cameroni E, 
Bowen JE, Tilles SW, Pizzuto MS, Guastalla SB, Bona G, Pellanda AF, Garzoni C, Van Voorhis WC, Rosen LE, Snell G, Telenti A, Virgin HW, Piccoli L, Corti D \& Veesler D (2021) SARS-CoV-2 immune evasion by variant B.1.427/B.1.429. Science 373, 648-654.

47 Garcia-Beltran WF, Lam EC, St. Denis K, Nitido AD, Garcia ZH, Hauser BM, Feldman J, Pavlovic MN, Gregory DJ, Poznansky MC, Sigal A, Schmidt AG, lafrate AJ, Naranbhai V \& Balazs AB (2021) Multiple SARS-CoV-2 variants escape neutralization by vaccine-induced humoral immunity. Cell 184, 2372-2383.e9.

48 Clark SA, Clark LE, Pan J, Coscia A, McKay LGA, Shankar S, Johnson RI, Brusic V, Choudhary MC, Regan J, Li JZ, Griffiths A \& Abraham J (2021) SARS-CoV-2 evolution in an immunocompromised host reveals shared neutralization escape mechanisms. Cell 184, 2605-2617.e18.

49 Choi B, Choudhary MC, Regan J, Sparks JA, Padera RF, Qiu X, Solomon IH, Kuo H-H, Boucau J, Bowman K, Adhikari U Das, Winkler ML, Mueller AA, Hsu TY-T, Desjardins M, Baden LR, Chan BT, Walker BD, Lichterfeld M, Brigl M, Kwon DS, Kanjilal S, Richardson ET, Jonsson AH, Alter G, Barczak AK, Hanage WP, Yu XG, Gaiha GD, Seaman MS, Cernadas M \& Li JZ (2020) Persistence and Evolution of SARS-CoV-2 in an Immunocompromised Host. N Engl J Med 383, 2291-2293.

50 Starr TN, Greaney AJ, Addetia A, Hannon WW, Choudhary MC, Dingens AS, Li JZ \& Bloom JD (2021) Prospective mapping of viral mutations that escape antibodies used to treat COVID-19. Science 371, 850-854.

51 Berkmen M (2012) Production of disulfide-bonded proteins in Escherichia coli. Protein Expr Purif 82, 240-251.

52 Ren G, Ke N \& Berkmen M (2016) Use of the SHuffle strains in production of proteins. Curr Protoc Protein Sci 2016, 5.26.1-5.26.21.

53 Shaywitz AJ, Dove SL, Kornhauser JM, Hochschild A \& Greenberg ME (2000) Magnitude of the CREB-Dependent Transcriptional Response Is Determined by the Strength of the Interaction between the Kinase-Inducible Domain of CREB and the KIX Domain of CREBBinding Protein. Mol Cell Biol 20, 9409-9422.

54 Ptacek J, Devgan G, Michaud G, Zhu H, Zhu X, Fasolo J, Guo H, Jona G, Breitkreutz A, Sopko R, McCartney RR, Schmidt MC, Rachidi N, Lee SJ, Mah AS, Meng L, Stark MJR, Stern DF, De Virgilio C, Tyers M, Andrews B, Gerstein M, Schweitzer B, Predki PF \& Snyder M (2005) Global analysis of protein phosphorylation in yeast. Nature 438, 679-684.

55 Errede B \& Levin DE (1993) A conserved kinase cascade for MAP kinase activation in yeast. Curr Opin Cell Biol 5, 254-260.

56 Hanks SK, Quinn AM \& Hunter T (1988) The protein kinase family: conserved features and deduced phylogeny of the catalytic domains. Science $241,42-52$.

57 Bouhaddou M, Memon D, Meyer B, White KM, Rezelj V V., Correa Marrero M, Polacco BJ, Melnyk JE, Ulferts S, Kaake RM, Batra J, Richards AL, Stevenson E, Gordon DE, Rojc A, Obernier K, Fabius JM, Soucheray M, Miorin L, Moreno E, Koh C, Tran QD, Hardy A, Robinot R, Vallet T, Nilsson-Payant BE, Hernandez-Armenta C, Dunham A, Weigang S, Knerr J, Modak M, Quintero D, Zhou Y, Dugourd A, Valdeolivas A, Patil T, Li Q, Hüttenhain

600 R, Cakir M, Muralidharan M, Kim M, Jang G, Tutuncuoglu B, Hiatt J, Guo JZ, Xu J, 
601

602

603

604

605

606

607

608

609

610

611

612

613

614

615

616

617

618

Bouhaddou S, Mathy CJP, Gaulton A, Manners EJ, Félix E, Shi Y, Goff M, Lim JK, McBride T, O'Neal MC, Cai Y, Chang JCJ, Broadhurst DJ, Klippsten S, De wit E, Leach AR, Kortemme T, Shoichet B, Ott M, Saez-Rodriguez J, tenOever BR, Mullins RD, Fischer ER, Kochs G, Grosse R, García-Sastre A, Vignuzzi M, Johnson JR, Shokat KM, Swaney DL, Beltrao P \& Krogan NJ (2020) The Global Phosphorylation Landscape of SARS-CoV-2 Infection. Cell 182, 685-712.e19.

58 Heller DM, Tavag M \& Hochschild A (2017) CbtA toxin of Escherichia coli inhibits cell division and cell elongation via direct and independent interactions with FtsZ and MreB. PLoS Gen 13, 1-38.

59 Althoff EA \& Cornish VW (2002) A Bacterial Small-Molecule Three-Hybrid System. Angew Chemie Int Ed 41, 2327-2330.

60 Zhao P, Praissman JL, Grant OC, Cai Y, Xiao T, Rosenbalm KE, Aoki K, Kellman BP, Bridger R, Barouch DH, Brindley MA, Lewis NE, Tiemeyer M, Chen B, Woods RJ \& Wells L (2020) Virus-Receptor Interactions of Glycosylated SARS-CoV-2 Spike and Human ACE2 Receptor. Cell Host Microbe 28, 586-601.e6.

61 Acharya A, Lynch DL, Pavlova A, Pang YT \& Gumbart JC (2021) ACE2 glycans preferentially interact with SARS-CoV-2 over SARS-CoV. Chem Commun 57, 5949-5952.

62 Mehdipour AR \& Hummer G (2021) Dual nature of human ACE2 glycosylation in binding to SARS-CoV-2 spike. Proc Natl Acad Sci U S A 118, e2100425118.

63 Du T, Buenbrazo N, Kell L, Rahmani S, Sim L, Withers SG, DeFrees S \& Wakarchuk W (2019) A Bacterial Expression Platform for Production of Therapeutic Proteins Containing Human-like O-Linked Glycans. Cell Chem Biol 26, 203-212.e5.

64 Planas D, Veyer D, Baidaliuk A, Staropoli I, Guivel-Benhassine F, Rajah MM, Planchais C, Porrot F, Robillard N, Puech J, Prot M, Gallais F, Gantner P, Velay A, Le Guen J, KassisChikhani N, Edriss D, Belec L, Seve A, Courtellemont L, Péré H, Hocqueloux L, FafiKremer S, Prazuck T, Mouquet H, Bruel T, Simon-Lorière E, Rey FA \& Schwartz O (2021) Reduced sensitivity of SARS-CoV-2 variant Delta to antibody neutralization. Nature 596, 276-280.

65 Shang J, Ye G, Shi K, Wan Y, Luo C, Aihara H, Geng Q, Auerbach A \& Li F (2020) Structural basis of receptor recognition by SARS-CoV-2. Nature 581, 221-224.

66 Luan B, Wang H \& Huynh T (2021) Enhanced binding of the N501Y-mutated SARS-CoV-2 spike protein to the human ACE2 receptor: insights from molecular dynamics simulations. FEBS Lett 595, 1454-1461.

67 Chan CEZ, Seah SGK, Chye DH, Massey S, Torres M, Lim APC, Wong SKK, Neo JJY, Wong PS, Lim JH, Loh GSL, Wang D, Boyd-Kirkup JD, Guan S, Thakkar D, Teo GH, Purushotorman K, Hutchinson PE, Young BE, Low JG, MacAry PA, Hentze H, Prativadibhayankara VS, Ethirajulu K, Comer JE, Tseng C-TK, Barrett ADT, Ingram PJ, Brasel T \& Hanson BJ (2021) The Fc-mediated effector functions of a potent SARS-CoV-2 neutralizing antibody, SC31, isolated from an early convalescent COVID-19 patient, are essential for the optimal therapeutic efficacy of the antibody. PLoS One 16, e0253487.

68 Ramanathan M, Ferguson ID, Miao W \& Khavari PA (2021) SARS-CoV-2 B.1.1.7 and B.1.351 spike variants bind human ACE2 with increased affinity. Lancet Infect Dis 21, 
1070.

644

69 Ali F, Kasry A \& Amin M (2021) The new SARS-CoV-2 strain shows a stronger binding affinity to ACE2 due to N501Y mutant. Med Drug Discov 10, 100086.

70 Villoutreix BO, Calvez V, Marcelin AG \& Khatib AM (2021) In silico investigation of the new UK (B.1.1.7) and South African (501y.v2) SARS-CoV-2 variants with a focus at the ace2spike rbd interface. Int $J$ Mol Sci 22, 1-13.

71 Socher E, Conrad M, Heger L, Paulsen F, Sticht H, Zunke F \& Arnold P (2021) Mutations in the B.1.1.7 SARS-CoV-2 Spike Protein Reduce Receptor-Binding Affinity and Induce a Flexible Link to the Fusion Peptide. Biomedicines 9, 525.

72 Huang SW \& Wang SF (2021) SARS-CoV-2 entry related viral and host genetic variations: Implications on covid-19 severity, immune escape, and infectivity. Int J Mol Sci 22, 1-22.

73 Greaney AJ, Loes AN, Crawford KHD, Starr TN, Malone KD, Chu HY \& Bloom JD (2021) Comprehensive mapping of mutations in the SARS-CoV-2 receptor-binding domain that affect recognition by polyclonal human plasma antibodies. Cell Host Microbe 29, 463476.e6.

74 Greaney AJ, Starr TN, Gilchuk P, Zost SJ, Binshtein E, Loes AN, Hilton SK, Huddleston J, Eguia R, Crawford KHD, Dingens AS, Nargi RS, Sutton RE, Suryadevara N, Rothlauf PW, Liu Z, Whelan SPJ, Carnahan RH, Crowe JE \& Bloom JD (2021) Complete Mapping of Mutations to the SARS-CoV-2 Spike Receptor-Binding Domain that Escape Antibody Recognition. Cell Host Microbe 29, 44-57.e9.

75 Laffeber C, de Koning K, Kanaar R \& Lebbink JHG (2021) Experimental Evidence for Enhanced Receptor Binding by Rapidly Spreading SARS-CoV-2 Variants. J Mol Biol 433, 167058.

76 Yi C, Sun X, Ye J, Ding L, Liu M, Yang Z, Lu X, Zhang Y, Ma L, Gu W, Qu A, Xu J, Shi Z, Ling Z \& Sun B (2020) Key residues of the receptor binding motif in the spike protein of SARS-CoV-2 that interact with ACE2 and neutralizing antibodies. Cell Mol Immunol 17, 621-630.

77 Deng X, Garcia-Knight MA, Khalid MM, Servellita V, Wang C, Morris MK, SotomayorGonzález A, Glasner DR, Reyes KR, Gliwa AS, Reddy NP, Sanchez San Martin C, Federman S, Cheng J, Balcerek J, Taylor J, Streithorst JA, Miller S, Sreekumar B, Chen PY, Schulze-Gahmen U, Taha TY, Hayashi JM, Simoneau CR, Kumar GR, McMahon S, Lidsky P V, Xiao Y, Hemarajata P, Green NM, Espinosa A, Kath C, Haw M, Bell J, Hacker JK, Hanson C, Wadford DA, Anaya C, Ferguson D, Frankino PA, Shivram H, Lareau LF, Wyman SK, Ott M, Andino R \& Chiu CY (2021) Transmission, infectivity, and neutralization of a spike L452R SARS-CoV-2 variant. Cell 184, 3426-3437.e8.

78 Motozono C, Toyoda M, Zahradnik J, Saito A, Nasser H, Tan TS, Ngare I, Kimura I, Uriu K, Kosugi Y, Yue Y, Shimizu R, Ito J, Torii S, Yonekawa A, Shimono N, Nagasaki Y, Minami R, Toya T, Sekiya N, Fukuhara T, Matsuura Y, Schreiber G, Ikeda T, Nakagawa S, Ueno T \& Sato K (2021) SARS-CoV-2 spike L452R variant evades cellular immunity and increases infectivity. Cell Host Microbe 29, 1124-1136.e11.

79 Tchesnokova V, Kulakesara H, Larson L, Bowers V, Rechkina E, Kisiela D, Sledneva Y, Choudhury D, Maslova I, Deng K, Kutumbaka K, Geng H, Fowler C, Greene D, Ralston J, 
Samadpour M \& Sokurenko E (2021) Acquisition of the L452R mutation in the ACE2binding interface of Spike protein triggers recent massive expansion of SARS-Cov-2 variants. J Clin Microbiol, doi:10.1128/JCM.00921-21.

80 Li Q, Wu J, Nie J, Zhang L, Hao H, Liu S, Zhao C, Zhang Q, Liu H, Nie L, Qin H, Wang M, Lu Q, Li X, Sun Q, Liu J, Zhang L, Li X, Huang W \& Wang Y (2020) The Impact of Mutations in SARS-CoV-2 Spike on Viral Infectivity and Antigenicity. Cell 182, 1284-1294.e9.

81 Kuznedelov K, Minakhin L, Niedziela-Majka A, Dove SL, Rogulja D, Nickels BE, Hochschild A, Heyduk T \& Severinov K (2002) A role for interaction of the RNA polymerase flap domain with the $\sigma$ subunit in promoter recognition. Science 295, 855-857.

82 Deighan P, Diez CM, Leibman M, Hochschild A \& Nickels BE (2008) The bacteriophage $\lambda$ Q antiterminator protein contacts the $\beta$-flap domain of RNA polymerase. Proc Natl Acad Sci 105, 15305-15310.

83 Chung CT, Niemela SL \& Miller RH (1989) One-step preparation of competent Escherichia coli: transformation and storage of bacterial cells in the same solution. Proc Natl Acad Sci 86, 2172-2175.

84 Deaconescu AM, Chambers AL, Smith AJ, Nickels BE, Hochschild A, Savery NJ \& Darst SA (2006) Structural Basis for Bacterial Transcription-Coupled DNA Repair. Cell 124, 507520.

85 Thibodeau SA, Fang R \& Joung JK (2004) High-throughput $\beta$-galactosidase assay for bacterial cell-based reporter systems. Biotechniques 36, 410-415. 
Fig. 1: Bacterial two-hybrid assay used to study the SARS-CoV-2 interactome. (A) (top) Schematic depiction of the employed transcription-based bacterial two-hybrid system. Interaction between protein moieties $X$ (purple) and $Y$ (slate blue), which are fused to the $N$ terminal domain of the $\alpha$ subunit of $E$. coli RNAP ( $\alpha$ NTD) and the $\lambda \mathrm{Cl}$ protein, respectively, stabilizes the binding of RNAP to test promoter placO $\mathrm{L}_{\llcorner} 2-62$, thereby activating transcription of the lac $Z$ reporter gene. The test promoter bears the $\lambda$ operator $O_{L} 2$ centered at position -62 upstream of the transcription start site. (bottom) $E$. coli cell containing genetic elements that are involved in the bacterial two-hybrid system. The chromosomal lacZ locus is deleted and the test promoter and fused lac $Z$ reporter gene are encoded on an F' episome. The $\lambda \mathrm{Cl}-\mathrm{Y}$ and $\alpha \mathrm{NTD}-\mathrm{X}$ fusion proteins are encoded on compatible plasmids and produced under the control of IPTGinducible promoters. (B) List of all tested SARS-CoV-2 ORFs as predicted by the NCBI reference genome (Accession \#: NC_045512.2). The respective nucleotide range for each ORF based on the NCBI reference sequence is indicated, together with the resulting amino acid sequence length. Except for the spike protein, all ORFs were cloned as full-length genes. For spike, we chose to test the interaction of its ectodomain (aa 16-1213) to avoid complications due to its $\mathrm{N}$-terminal signal peptide and C-terminal transmembrane domain.

Fig. 2: Detection of protein-protein interactions by the bacterial two-hybrid system. Interaction matrix of all tested ORFs. Positive interactions, regardless of the fusion partner, are indicated with purple squares and self-interactions are indicated by orange-framed squares. Detailed information about fusion constructs for which positive interactions were identified is given in Supplementary Fig. 1. To avoid data duplication, only one half of the matrix is shown while the other is shaded in grey.

Fig. 3: Strong SARS-CoV-2 protein-protein interactions identified by $\mathbf{B 2 H}$ assays. Shown are two-hybrid data for strong interactions (arbitrarily defined as Miller units $>500$ ). Indicated ORFs are fused either to the $\alpha$ NTD (indicated as $\alpha$ ) or to full-length $\lambda \mathrm{Cl}$ (indicated as $\mathrm{Cl}$ ). $\alpha$ and

$734 \lambda \mathrm{Cl}$ negative controls express full-length $\alpha$ and full-length $\lambda \mathrm{Cl}$, respectively. The interaction of domain 4 of the RNAP $\sigma^{70}$ subunit (fused to the $\alpha$ NTD) with the flap domain of the RNAP $\beta$

736 subunit (fused to $\lambda \mathrm{Cl}$ ) served as a positive control (pos) $[81,82]$. Bar graphs show the averages 737 of three biological replicates $(n=3)$ and $\beta$-galactosidase activities are given in Miller units. Error 738 bars indicate the standard deviation. Values indicated with asterisks are significantly different 739 from the negative control. ${ }^{* \star * *}: \mathrm{P}<0.0001$ (One-way ANOVA with Turkey's multiple comparison 740 test). 
Fig. 4: Selective disruption of protein interfaces for protein with two interaction partners. (A) Depiction of crystal structure (PDB ID: 5NFY [29]) of SARS-CoV-1 Nsp10 (pale cyan) in complex with Nsp14 (pale pink). Zoom-in shows amino acids (sticks) chosen for mutational analysis of Nsp10 (orange, olive, and burgundy) and their corresponding main interaction partners in Nsp14 (pale pink). (B) B2H results showing effects of Nsp10 substitutions on its interactions with Nsp14 and with Nsp16. Amino acid substitutions introduced into Nsp10 are given in the box. (C) Depiction of crystal structure of the SARS-CoV-2 Nsp16-Nsp10 protein complex (PDB ID: 6W4H [31]) colored respectively in pale yellow and pale cyan. Additional Nterminal Nsp1 $0^{7-22}$ region is included and was obtained from superimposed Nsp10 structure from PDB ID: $5 \mathrm{NFY}$ (green). Zoom-in shows amino acids (sticks) chosen for mutational analysis of Nsp16 (orange and burgundy) and their corresponding main interaction partners in Nsp10 (pale cyan). (D) B2H results showing effects of Nsp16 substitutions on its interactions with Nsp10 and with Nsp15. Amino acid substitutions introduced into Nsp16 are given in the box. $(B, D)$ Indicated ORFs are fused either to the $\alpha$ NTD (indicated as $\alpha$ ) or to full-length $\lambda \mathrm{Cl}$. $\alpha$ and $\lambda \mathrm{Cl}$ negative controls express full-length $\alpha$ and full length $\lambda \mathrm{Cl}$, respectively. Bar graphs show the averages of three biological replicates $(n=3)$ and $\beta$-galactosidase activities are given in Miller units. Error bars indicate the standard deviation. Values indicated with asterisks are significantly different from the WT. ns: not significant; ${ }^{*}$ : $\mathrm{P}<0.05$; ${ }^{* *}$ : $\mathrm{P}<0.01$; ${ }^{* * *}$ : $\mathrm{P}<0.0001$ (One-way ANOVA with Dunnett's multiple comparison test). Black dashed lines in $\mathbf{A}$ and $\mathbf{C}$ represent

Fig. 5: Interaction of spike RBD and ACE2 in an oxidizing E. coli strain. (A) Bacterial twohybrid assays of (A) spike domains (as listed in Supplementary Fig. 7) tested against ACE2 in BLS148, (B) indicated spike RBD cysteine mutants tested against ACE2 in BLS148 and B2H or (C) indicated spike RBD circulating variants tested against ACE2 in BLS148. FL: full-length, NTD: N-terminal domain; RBD: receptor binding domain; CTD: C-terminal domain (with or without transmembrane domain (TMD)), Ecto: Ectodomain starting either at aa 13 or 16. (D) Schematic depicting amino acid substitutions present in each of three RBD variants tested. The measured effect of each substitution on ACE2 binding is indicated with a dash (no effect), a downward pointing arrow (weakened binding) or an upward pointing arrow (strengthened binding). (A-C) spike domains or RBD mutant variants were fused to the $\alpha$ NTD (indicated as $\alpha$ ) and ACE2 was fused to full-length $\lambda \mathrm{Cl}$. $\alpha$ and $\lambda \mathrm{Cl}$ negative controls express full-length $\alpha$ and full-length $\lambda \mathrm{Cl}$, respectively. Bar graphs show $(\mathbf{A})$ one biological replicate or $(\mathbf{B}, \mathbf{C})$ the averages of three biological replicates $(n=3)$ and $\beta$-galactosidase activities are given in Miller units. Note: results depicted in (C) have been confirmed in a total of seven independent experiments, one of which is shown here. Error bars indicate the standard deviation. Values indicated with asterisks are significantly different from the negative control. ns: not significant; ${ }^{*}: \mathrm{P}<0.05 ;{ }^{* *}: \mathrm{P}<0.01$; ${ }^{* * * *}$ : $\mathrm{P}<0.0001$ (Two-way ANOVA with Turkey's multiple comparison test). Western blot analysis

780 comparable to the wild-type RBD, ruling out protein instability as a cause for the observed 781 effects (Supplementary Figs. 8 and 9). 
783 Supplementary Fig. 1: Fusion constructs of positive $\mathbf{B 2 H}$ interactions. List of all $\mathrm{B} 2 \mathrm{H}-$ 784 identified SARS-CoV-2 PPIs. Green-shaded rectangles indicate the plasmid from which Protein 785 A (first-mentioned protein in the left column) is produced to elicit a positive interaction with 786 Protein B encoded by the other plasmid. When an interaction of Protein A and Protein B was 787 identified regardless of the encoding plasmid, rectangles are shaded green in the column "both".

788 Supplementary Fig. 2: Medium-to-weak SARS-CoV-2 protein-protein interactions 789 identified B2H assays. Shown are two-hybrid data for medium-to-weak interactions (Miller unit 790 values between 2- and 5-fold above the negative control Miller unit value). Indicated ORFs are 791 fused either to the $\alpha$ NTD (indicated as $\alpha$ ) or to full-length $\lambda \mathrm{Cl}$ (indicated as $\mathrm{Cl}$ ). $\alpha$ and $\lambda \mathrm{Cl}$ 792 negative controls express full-length $\alpha$ and full-length $\lambda \mathrm{Cl}$, respectively. The interaction of 793 domain 4 of the RNAP $\sigma^{70}$ subunit (fused to the $\alpha$ NTD) with the flap domain of the RNAP $\beta$ 794 subunit (fused to $\lambda \mathrm{Cl}$ ) served as a positive control (pos) [81,82]. Bar graphs show the averages 795 of three biological replicates $(n=3)$ and $\beta$-galactosidase activities are given in Miller units. Error 796 bars indicate the standard deviation. Values indicated with asterisks are significantly different 797 from the negative control. ${ }^{* * *}: \mathrm{P}<0.001 ;{ }^{* * *}: \mathrm{P}<0.0001$ (One-way ANOVA with Turkey's multiple 798 comparison test).

799 Supplementary Fig. 3: Comparison of $\mathbf{B 2 H}$ with $\mathrm{Y2H}$ and co-IP data. Interaction matrix 800 showing all SARS-CoV-2 PPIs identified with the $\mathrm{B} 2 \mathrm{H}$ assay (this study) or with the $\mathrm{Y} 2 \mathrm{H}$ and co801 IP assays [6]. Squares designating PPIs identified solely by the $\mathrm{B} 2 \mathrm{H}$ assay are colored purple 802 and contain a white disc, whereas squares designating PPIs identified solely by the $\mathrm{Y} 2 \mathrm{H}$ assay 803 or by co-IP experiments are colored red and blue, respectively. Squares designating 804 interactions that were identified by two or three of the assays contain the respective colors as 805 indicated in the key at the left side of the matrix.

806 Supplementary Fig. 4: Comparison of SARS-CoV-2 B2H data with SARS-CoV-1 two807 hybrid data. Interaction matrix showing the sixteen PPIs identified with the B2H assay (this 808 study) and indicating which of these PPIs were also identified in at least one of three previous 809 SARS-CoV-1 two hybrid studies, including two $\mathrm{Y} 2 \mathrm{H}$ analyses [7,27] and one mammalian two810 hybrid analysis [26]. Squares designating PPIs identified solely by the $\mathrm{B} 2 \mathrm{H}$ assay are colored 811 purple and contain a white disc. Coloring within the central disc designates a PPI that was also 812 identified in one or two of the SARS-CoV-1 two-hybrid analyses (von Brunn et al. [7], orange; 813 Imbert et al. [27], yellow; Pan et al. [26], cyan). Note that none of the PPIs were identified in all 814 three SARS-CoV-1 analyses. 

and Nsp16 fusion proteins. (top) Anti- $\alpha$ NTD and (bottom) anti- $\lambda \mathrm{Cl}$ western blot of cell lysates taken from over-night cultures of cells used for $\mathrm{B} 2 \mathrm{H}$ analysis shown in Fig. 4B. Samples in lanes 1-5 are from cells producing the indicated $\lambda \mathrm{Cl}-\mathrm{Nsp} 10$ fusion protein or $\lambda \mathrm{Cl}$ (see key) and the $\alpha$-Nsp16 fusion protein, whereas samples in lanes 10-14 are from cells producing the indicated $\lambda \mathrm{Cl}-\mathrm{Nsp} 10$ fusion protein or $\lambda \mathrm{Cl}$ and the $\alpha$-Nsp14 fusion protein. Samples in lanes 6-9 are from cells producing the indicated $\lambda \mathrm{Cl}$-Nsp10 fusion protein and full-length $\alpha$. We note that substitutions D29A+S33A appeared to be mildly destabilizing, whereas substitutions $\mathrm{F} 16 \mathrm{~A}+\mathrm{F} 19 \mathrm{~A}+\mathrm{V} 21 \mathrm{~A}$ appeared to be mildly stabilizing. and Nsp16 fusion proteins. (top) Anti- $\alpha$ NTD and (bottom) anti- $\lambda \mathrm{Cl}$ western blot of cell lysates taken from over-night cultures of cells used for the subsequent B2H analysis shown in Fig. 4D. Samples in lanes 1-5 are from cells producing the indicated $\alpha$-Nsp16 fusion protein or $\alpha$ (see key) and the $\lambda \mathrm{Cl}-\mathrm{Nsp} 10$ fusion protein, whereas samples in lanes 10-14 are from cells producing the indicated $\alpha$-Nsp16 fusion protein or $\alpha$ and the $\lambda \mathrm{Cl}-\mathrm{Nsp} 15$ fusion protein. Samples in lanes 6-9 are from cells producing the indicated $\alpha$-Nsp16 fusion protein and full-length $\lambda \mathrm{Cl}$. Lanes indicated with " $X$ " are not discussed in the current manuscript but were not cut from the blot to avoid excessive manipulations of the original image. Note: Native, chromosomally encoded full-length $\alpha$ is detected in all samples.

834 Supplementary Fig. 7: Domains of the SARS-CoV-2 spike protein. Depiction of SARS-CoV8352 spike domains, including the signal peptide (SP, predicted from aa 1-13 or 1-16), the N836 terminal domain (NTD, aa 1-330), the receptor binding domain (RBD, aa 331-521), the C837 terminal domain (CTD, aa 522-1273) and the transmembrane domain (TMD, aa 1202-1273). 838 The table lists the spike domains that were produced in $E$. coli (as B2H fusion proteins) and 839 tested for interaction with ACE2, their precise corresponding loci on the SARS-CoV-2 genome, and the amino acids encoded by each test domain. fusion proteins in oxidizing vs. reducing $E$. coli test strains. (top) Anti- $\alpha$ NTD and (bottom) anti- $\lambda \mathrm{Cl}$ Western blot of cell lysates taken from over-night cultures of BLS148 or B2H cells used for the subsequent two-hybrid analyses shown in Fig. 5B. Samples in lanes 1-5 and 10-14 are from BLS148 cells and B2H cells, respectively, producing the indicated $\alpha$-RBD fusion protein or $\alpha$ (see key) and the $\lambda \mathrm{Cl}$-ACE2 fusion protein, whereas samples in lanes 6-9 and 15-18 are from BLS148 cells and B2H cells, respectively, producing the indicated $\alpha$-RBD fusion protein and fulllength $\lambda \mathrm{Cl}$. Lanes indicated with " $X$ " are not discussed in the current manuscript but were not cut from the blot to avoid excessive manipulations of the original image. White dotted line indicates stitched image where extraneous material was removed. Note: Native, chromosomally

852 Supplementary Fig. 9: Western blot analysis showing intracellular levels of spike RBD 853 mutants. (top) Anti- $\alpha-N T D$ and (bottom) anti- $\lambda \mathrm{Cl}$ western blot of cell lysates taken from over854 night cultures of BLS148 cells used for the subsequent two-hybrid analysis shown in Fig. 5C. 
855 Samples in lanes 1-9 are from cells producing the indicated $\alpha$-RBD fusion protein or $\alpha$ (see key)

856 and the $\lambda \mathrm{Cl}$-ACE2 fusion protein, whereas samples in lanes 10-17 are from cells producing the 857 indicated $\alpha$-RBD fusion protein and full-length $\lambda \mathrm{Cl}$. Note: Native, chromosomally encoded full858 length $\alpha$ in all samples.

\section{Supplementary Table Legends}

860 Supplementary Table 1: List of (A) strains and plasmids, and (B) oligonucleotide primers used 861 in this study. 


\section{Acknowledgments}

863 We thank Eleanor Fleming, Zoë Feder, Kemardo Henry, EmilyKate McDonough, Hanif

864 Vahedian Movahed and Simon Dove for valuable discussion; Simon Dove and Jonathan

865 Abraham for comments on the manuscript; and Sydney Rosa Teixeira for technical support.

866 BLS, PD and AH were supported by a "Maximizing Investigators' Research Award" (MIRA; No.

867 R35GM136247) awarded to $\mathrm{AH}$.

\section{Author contribution}

$869 \mathrm{AH}$ and BLS designed the study. BLS performed the experimental work with support from PD.

870 GG analyzed crystal structure data and provided predictions for the mutational screens. BLS

871 and $\mathrm{AH}$ drafted the manuscript with contributions from all coauthors.

\section{Competing interests}

873 The authors declare no competing interests.

\section{Data availability}

875 All data generated during and/or analyzed during the current study are either provided within the 876 manuscript or are available from the corresponding authors upon reasonable request. 
879 E. coli strains MAX Efficiency ${ }^{\mathrm{TM}} \mathrm{DH} 5 \alpha \mathrm{F}^{\prime} \mathrm{IQ}$ (Invitrogen) and NEB® 5-alpha F'IQ (New England

880 Biolabs, NEB) were used for routine cloning procedures and chemically competent $E$. coli were

881 transformed with plasmid DNA by the standard heat shock procedure. FW102 $\mathrm{O}_{\llcorner} 2-62$ and

882 BLS148 strains were used for bacterial two-hybrid assays. All strains listed in Supplementary

883 Table $1 \mathrm{~A}$ were grown in LB medium containing the appropriate antibiotics at standard

884 concentrations. BLS148 was created by P1 phage transduction of $\triangle$ laclZYA::kmR from strain

885 TB12 (P1 phage lysates were a gift from Thomas Bernhardt, Harvard Medical School) to

886 SHuffle ${ }^{\circledR}$ Express (NEB) according to a protocol established by Robert T. Sauer (Massachusetts

887 Institute of Technology; protocol available at:

888 https://openwetware.org/wiki/Sauer:P1vir phage transduction), generating BLS128. Deletion of

889 lacZ in BLS128 was verified by colony PCR (using primers oBLS107+oBLS108 targeting lacZ to

890 test for absence of lacZ and primers oBLS109+oBLS110 targeting mot $A$ and primers

891 oBLS138+oBLS139 targeting cyaA as control reactions). Next, TSS competent BLS128 cells

892 were created according to [83], transformed with pCP20 (encoding the yeast Flp recombinase

893 gene to flip out the kanamycin resistance gene) and grown over night at $30{ }^{\circ} \mathrm{C}$ on LB plates

894 containing carbenicillin $(100 \mu \mathrm{g} / \mathrm{ml}$; Carb100). The next day, 10 colonies were picked and re-

895 streaked on LB plates without antibiotics and then grown over night at $42{ }^{\circ} \mathrm{C}$. From each of

896 those strains a single colony was picked and re-streaked on LB plates containing either

897 Carb100, kanamycin $(20 \mu \mathrm{g} / \mathrm{ml}$; Km20) or spectinomycin (50 $\mu \mathrm{g} / \mathrm{ml}$, Sp50) and grown over night

898 at $30{ }^{\circ} \mathrm{C}$. A single Sp50 resistant but Carb100 and Km20 sensitive colony was picked and re-

899 verified by streaking on the same growth plates. This strain that had lost the $k m R$ resistance

900 cassette was then designated BLS133. Finally, the $\beta$-galactosidase reporter present on the F'

901 was introduced into BLS133 by mating with strain FW102 OL2-62 [84]. For this, both BLS133 
902 and $\mathrm{FW} 102 \mathrm{O}_{\mathrm{L}} 2-62$ were grown over night at $37^{\circ} \mathrm{C}$ in LB Sp50 or $\mathrm{Km} 20$, respectively, and then

903 streaked on top of each other on the same LB plate. After about 8 hours at $37^{\circ} \mathrm{C}$ cells were

904 resuspended in LB and plated in serial dilutions on LB plates containing Sp50, Km20 and X-gal

905 (40 $\mu \mathrm{g} / \mathrm{ml} ; \mathrm{X}-\mathrm{gal} 40)$ and then grown over night at $37^{\circ} \mathrm{C}$. A blue colony was picked and re-

906 verified by streaking again on a LB plate containing Sp50, Km20 and X-gal40, creating BLS148,

907 a bacterial two-hybrid-compatible SHuffle ${ }^{\circledR}$ Express strain.

909 All plasmids generated in this study (see Supplementary Table 1A) were either constructed

910 using standard restriction enzyme-based cloning procedures or by Gibson assembly. Gibson

911 assembly was performed for $1 \mathrm{~h}$ at $50^{\circ} \mathrm{C}$ by default. Primers employed for plasmid construction

912 are listed in Supplementary Table 1B. Plasmid sequence integrity was verified by Sanger

913 sequencing from Genewiz or Quintarabio (both Boston, MA, USA). Unless otherwise stated, all

914 sequence templates, except for Nsp11, were ordered as E. coli codon-optimized gene

915 fragments from Twist Bioscience (San Francisco, CA, USA).

916 Except for spike, Nsp2, Nsp3, RNA-Polymerase (Nsp12) and helicase (Nsp13), all full-length

917 codon-optimized gene fragments were digested with Notl+BamHI, purified by DNA Clean \&

918 Concentrator kit (Zymo Research) and then ligated into 50 ng Notl+BamHI-digested pBR $\alpha$ or

$919 \mathrm{pAC} \lambda \mathrm{Cl}$ using T4 ligase (NEB) according to standard protocols generating the plasmids listed in

920 Supplementary Table $1 \mathrm{~A}$.

921 Spike: For pS63, the spike full-length (FL) sequence was amplified from E. coli codon-optimized

922 gene fragments by SARS_67+SARS_68 and cloned into Notl+BamHI-digested pBR $\alpha$ by Gibson

923 assembly. For pS64, the NTD sequence was amplified from pS63 by SARS_67+SARS_69 and

924 then cloned into Notl+BamHI-digested $\mathrm{pBR} \alpha$ by Gibson assembly. For $\mathrm{pS65}$, the RBD

925 sequence was amplified from pS63 by SARS_70+SARS_71 and then cloned into Notl+BamHI- 
926 digested pBR $\alpha$ by Gibson assembly. For pS66, the CTD sequence was amplified from pS63 by

927 SARS_68+SARS_72 and then cloned into Notl+BamHI-digested pBR $\alpha$ by Gibson assembly.

928 For pS67, the Ectodomain (aa 13-1213) was amplified from pS63 by SARS_73+SARS_74 and

929 then cloned into Notl+BamHI-digested $\mathrm{pBR} \alpha$ by Gibson assembly. For pS68, the Ectodomain

930 (aa 16-1213) was amplified from pS63 by SARS_74+SARS_75 and then cloned into

931 Notl+BamHI-digested $\mathrm{pBR} \alpha$ by Gibson assembly. pS70 was generated by site-directed

932 mutagenesis (SDM; see below) using primers SARS_17+SARS_76 and pS63 as a template.

933 For pS72, FL spike was amplified from pS63 by SARS_77+SARS_78 and then cloned into

934 Notl+BamHI-digested $\mathrm{pAC} \lambda \mathrm{Cl}$ by Gibson assembly. For pS73, the NTD sequence was amplified

935 from pS63 by SARS_77+SARS_79 and then cloned into Notl+BamHI-digested pAC $\lambda \mathrm{Cl}$ by

936 Gibson assembly. For pS74, the RBD sequence was amplified from pS63 by

937 SARS_80+SARS_81 and then cloned into Notl+BamHI-digested pAC $\lambda \mathrm{Cl}$ by Gibson assembly.

938 For pS75, the CTD sequence was amplified from pS63 by SARS_78+SARS-82 and then cloned

939 into Notl+BamHI-digested $\mathrm{pAC \lambda Cl}$ by Gibson assembly. For pS76, the Ectodomain (aa 13-

940 1213) was amplified from pS63 by SARS_83+SARS_84 and then cloned into Notl+BamHI-

941 digested pAC $\lambda \mathrm{CI}$ by Gibson assembly. For pS77, the Ectodomain (aa 16-1213) was amplified

942 from pS63 by SARS_84+SARS_85 and then cloned into Notl+BamHI-digested pAC $\lambda \mathrm{Cl}$ by

943 Gibson assembly. pS79 was generated by SDM using primers SARS_17+SARS_86 and pS63

944 as a template.

945 Nsp2: The Nsp2 sequence was ordered as two single gene fragments, which were further 946 amplified by PCR using primers SARS_109+SARS_110 or SARS_111+SARS_112 and then

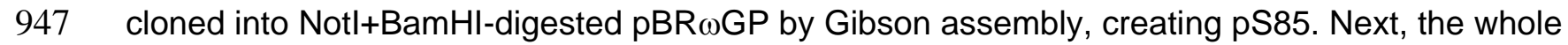

948 Nsp2 open reading frame (ORF) was cut from pS85 by Notl+BamHI and inserted into $50 \mathrm{ng}$ 
949 Notl+BamHI-digested $\mathrm{pBR} \alpha$ or $\mathrm{pAC} \lambda \mathrm{Cl}$ using T4 ligase (NEB) according to standard protocols, 950 creating pS179 and pS180, respectively.

951 Nsp3: The Nsp3 sequence was ordered as four single gene fragments, which were further

952 amplified by PCR using primers SARS_115+SARS_116, SARS_117+SARS_118,

953 SARS_119+SARS_120 or SARS_121+SARS_122 and then cloned into Notl+BamHI-digested

954 pBR $\omega$ GP by Gibson assembly, creating pS89. Next, the whole Nsp3 open reading frame (ORF)

955 was cut from pS89 by Notl+BamHI and inserted into $50 \mathrm{ng} \mathrm{Notl+BamHI-digested} \mathrm{pBR \alpha} \mathrm{or}$

$956 \mathrm{pAC} \lambda \mathrm{Cl}$ using T4 ligase (NEB) according to standard protocols, creating pS181 and pS182, 957 respectively.

958 RNA-Polymerase (Nsp12): The RNA-Polymerase sequence was ordered as three single gene 959 fragments, which were further amplified by PCR using primers SARS_131+SARS_132, 960 SARS_133+SARS_134 or SARS_135+SARS_136 and then cloned into Notl+BamHI-digested 961 pBR $\omega$ GP by Gibson assembly, creating pS173. Next, the whole Nsp3 open reading frame 962 (ORF) was cut from pS89 by Notl+BamHI and inserted into 50 ng Notl+BamHI-digested pBR $\alpha$ 963 or $\mathrm{pAC} \lambda \mathrm{Cl}$ using T4 ligase (NEB) according to standard protocols, creating pS181 and pS182, 964 respectively.

965 helicase (Nsp13): The helicase sequence was ordered as two single gene fragments, which 966 were further amplified by PCR using primers SARS_125+SARS_126 or SARS_127+SARS_128

967 and then cloned into Notl+BamHI-digested pBR $\omega$ GP by Gibson assembly, creating pS169.

968 Next, the whole Nsp2 open reading frame (ORF) was cut from pS85 by Notl+BamHI and 969 inserted into 50 ng Notl+BamHI-digested $\mathrm{pBR} \alpha$ or $\mathrm{pAC} \lambda \mathrm{Cl}$ using T4 ligase (NEB) according to 970 standard protocols, creating pS221 and pS222, respectively. 
971 ACE2: The ACE2 N-terminal peptidase domain (aa 19-615) was ordered as a single gene

972 fragment and then further amplified by PCR using primers SARS_264+SARS_265 or

973 SARS_266+SARS_267 and then cloned into $50 \mathrm{ng}$ Notl+BamHI-digested pBR $\alpha$ or pAC $\lambda \mathrm{Cl}$ by

974 Gibson assembly, creating pS260 and pS261, respectively.

975 Nsp11 was cloned into $\mathrm{pBR} \alpha$ or $\mathrm{pAC} \lambda \mathrm{Cl}$ as annealed primers. For this, $10 \mu \mathrm{l}$ of $100 \mu \mathrm{M}$ 976 SARS_139 and SARS_140 primers were mixed with $1 \mu \mathrm{l}$ T4 Polynucleotide kinase (PNK; NEB)

977 in 1x PNK reaction buffer (NEB). The reaction mix was placed in a BioRad T100 Thermal cycler, 978 incubated for $30 \mathrm{~min}$ at $37^{\circ} \mathrm{C}$, inactivated for $5 \mathrm{~min}$ at $95^{\circ} \mathrm{C}$ and then cooled to $4{ }^{\circ} \mathrm{C}$ at a 0.1

$979{ }^{\circ} \mathrm{C} / \mathrm{s}$ ramp rate. The annealed oligos were diluted 1:50 and then ligated into 50 ng Notl+BamHI-

980 digested $\mathrm{pBR} \alpha$ or $\mathrm{pAC} \lambda \mathrm{Cl}$ using T4 ligase (NEB), generating pS197 and pS198, respectively.

$981 \quad$ Plasmid mutagenesis

982 Plasmid mutagenesis to create SARS-CoV-2 mutant genes was achieved using the Q5 ${ }^{\circledR}$ Site-

983 Directed Mutagenesis (SDM) Kit according to the manufacturer's instructions (NEB) or by using

984 Gibson assembly with mutations introduced into the complementary overhang regions of the

985 primer sequences. For the Gibson assembly, plasmids were amplified with the indicated primer

986 pairs and $1 \mu \mathrm{l}$ of the resulting PCR reaction was then ligated by Gibson assembly in a $10 \mu \mathrm{l}$

987 reaction volume.

988 pS254 was generated by SDM using primers SARS_253+SARS_254 and plasmid pS215 as a 989 template. pS256 was generated by SDM using primers SARS_256+SARS_257 and plasmid 990 pS215 as a template. pS257 was generated by SDM using primers SARS_256+SARS_257 and 991 plasmid pS254 as a template. pS262 was generated by Gibson assembly using primers

992 SARS_268+SARS_269 and plasmid pS196 as a template. pS263 was generated by Gibson 993 assembly using primers SARS_270+SARS_271 and plasmid pS196 as a template. pS264 was 994 generated by Gibson assembly using primers SARS_272+SARS_273 and plasmid pS196 as a 
995 template. pS267 was generated by Gibson assembly using primers SARS_280+SARS_281 and

996 plasmid pS65 as a template. pS271 was generated by Gibson assembly using primers

997 SARS_287+SARS_288 and plasmid pS65 as a template. pS272 was generated by Gibson

998 assembly using primers SARS_289+SARS_290 and plasmid pS65 as a template. pS273 was

999 generated by Gibson assembly using primers SARS_289+SARS_290 and plasmid pS271 as a

1000 template. pS275 was generated by Gibson assembly using primers SARS_295+SARS_296 and

1001 plasmid pS65 as a template. pS276 was generated by Gibson assembly using primers

1002 SARS_291+SARS_292 and plasmid pS65 as a template. pS277 was generated by Gibson

1003 assembly using primers SARS_293+SARS_294 and plasmid pS65 as a template. pS278 was

1004 generated by Gibson assembly using primers SARS_291+SARS_292 and plasmid pS267 as a

1005 template. pS279 was generated by Gibson assembly using primers SARS_293+SARS_294 and

1006 plasmid pS267 as a template. pS280 was generated by Gibson assembly using primers

1007 SARS_293+SARS_294 and plasmid pS278 as a template.

$1008 \quad \beta$-galactosidase assays

$1009 \beta$-galactosidase assays to study the SARS-CoV-2 interactome were performed essentially as 1010 described previously [85]. In particular, $\mathrm{pBR} \alpha$ and $\mathrm{pAC} \lambda \mathrm{Cl}$ plasmids containing the indicated 1011 inserts were co-transformed into FW102 OL2-62 by the heat shock procedure. Briefly, $2 \mu \mathrm{l}$ of 1012 each plasmid (1:10 dil.) were mixed with $20 \mu$ chemically competent FW102 $\mathrm{L}_{\llcorner} 2-62$ cells, 1013 incubated on ice in 96-well PCR plates (VWR) for $30 \mathrm{~min}$ and then heat-shocked for $1 \mathrm{~min}$ at 42 $1014{ }^{\circ} \mathrm{C}$ in a BioRad T100 Thermal cycler. Cells were placed on ice for $5 \mathrm{~min}$, recovered in $80 \mu \mathrm{l}$ 1015 fresh LB medium and then incubated at $37^{\circ} \mathrm{C}$ for $1 \mathrm{~h}$ (Please note: we found that commercially 1016 available premixed LB drastically reduces transformation efficiency and also subsequent over 1017 night culture growth; we thus recommend using non-premixed LB medium instead). The 96-well 1018 plates were sealed with Rayon Films (VWR) to allow proper aeration and prevent 1019 contamination. Afterwards, $50 \mu \mathrm{l}$ of transformed cells were transferred to $2 \mathrm{ml}$ deep well plates 
1020 containing $500 \mu \mathrm{L}$ LB Carb100, chloramphenicol $(25 \mu \mathrm{g} / \mathrm{ml}$; Cm25), Km20 and $5 \mu \mathrm{M}$ IPTG and 1021 grown over night at $37^{\circ} \mathrm{C}, 800 \mathrm{rpm}$. The next day, $4 \mu \mathrm{l}$ over-night culture was transferred to 961022 well flat bottom microtiter plates containing $200 \mu \mathrm{LB}$ Carb100, Cm25, Km20 and $20 \mu \mathrm{M}$ IPTG 1023 and grown until approx. $\mathrm{OD}_{600}$ 0.15-0.2 (measured in a VERSA Max microplate reader, 1024 Molecule Devices, San Jose, CA, USA). Then, $20 \mu$ lysis solution (for one 96-well plate mix: 1.2 $1025 \mathrm{ml}$ PopCulture ${ }^{\circledR}$ Reagent (MilliporeSigma, MA, USA), $2.5 \quad \mu l \quad 400 \mathrm{U} / \mu \mathrm{l}$ rLysozyme $\mathrm{r}^{\mathrm{TM}}$ 1026 (MilliporeSigma, MA, USA) and $1.25 \mu$ l Benzonase ${ }^{\circledR}$ Nuclease (MilliporeSigma, MA, USA)) was 1027 added to the cells and incubated for at least $30 \mathrm{~min}$ at $37^{\circ} \mathrm{C}$ and $800 \mathrm{rpm}$ (longer incubation 1028 times were found to not negatively affect the experimental results). Afterwards, $30 \mu$ lysed cell 1029 suspension was added to a fresh 96-well flat-bottom microtiter plate containing $150 \mu \mathrm{Z}$ Z1030 buffer/ONPG solution (60 mM Na $2 \mathrm{HPO}_{4}, 40 \mathrm{mM} \mathrm{NaH} \mathrm{PO}_{4}, 10 \mathrm{mM} \mathrm{KCl}, 1 \mathrm{mM} \mathrm{MgSO}, 1 \mathrm{mg} / \mathrm{ml}$ 1031 ortho-Nitrophenyl- $\beta$-galactoside (ONPG)) and $\mathrm{OD}_{420}$ values were recorded in a VERSA Max 1032 microplate reader (Molecule Devices, San Jose, CA, USA). $\beta$-galactosidase activity in Miller 1033 units was then calculated as described previously [85].

$1034 \beta$-galactosidase assays to study the RBD-ACE2 interaction were performed as follows. Strain 1035 BLS148 was transformed with the appropriate plasmids, as described in the preceding 1036 paragraph. Upon recovery of the transformed cells for $1 \mathrm{~h}$ at $37^{\circ} \mathrm{C}, 50 \mu \mathrm{l}$ cells were then 1037 transferred to $500 \mu \mathrm{l}$ LB Carb100, Km20, Cm25 and $50 \mu \mathrm{M}$ IPTG and grown for approx. $20 \mathrm{~h}$ at $103830^{\circ} \mathrm{C}$ and $800 \mathrm{rpm}$. Subsequently, $15 \mu \mathrm{l}$ cells were transferred to $185 \mu \mathrm{l}$ LB medium in 96-well 1039 microtiter plates, combined with $20 \mu$ lysis solution (for one 96-well plate: 1.2 ml PopCulture ${ }^{\circledR}$ 1040 Reagent (MilliporeSigma, MA, USA), $5.0 \mu \mathrm{l}$ 400U/ $\mu \mathrm{l}$ rLysozyme ${ }^{\mathrm{TM}}$ (MilliporeSigma, MA, USA) 1041 and $2.5 \mu \mathrm{l}$ Benzonase ${ }^{\circledR}$ Nuclease (MilliporeSigma, MA, USA)) and incubated for at least $30 \mathrm{~min}$ 1042 at $30{ }^{\circ} \mathrm{C}, 800 \mathrm{rpm}$. All subsequent steps were then performed as described above. 


\section{Western blot analysis}

1045 To verify the production of the respective fusion proteins, western blots of cell lysates from over-

1046 night cultures were performed. For this, co-transformed cells were grown in the indicated IPTG

1047 concentration over-night in $550 \mu \mathrm{l}$ total volume in $2 \mathrm{ml}$ deep well plates at 30 or $37^{\circ} \mathrm{C}, 800 \mathrm{rpm}$.

1048 The next day, $\mathrm{OD}_{600}$ values were recorded and $500 \mu \mathrm{l}$ cells were pelleted by centrifugation (1

$1049 \min , 21,000 \times \mathrm{g}$, room temperature $(\mathrm{RT}))$ and either stored at $-80^{\circ} \mathrm{C}$ or directly processed. Cell

1050 pellets were then resuspended in lysis buffer (BugBuster® Protein Extraction Reagent

1051 (MilliporeSigma, MA, USA) supplemented with 1x cOmplete ${ }^{\mathrm{TM}}$, EDTA-free Protease Inhibitor

1052 Cocktail (MilliporeSigma, MA, USA), $1 \mathrm{U} / \mu \mathrm{l}$ rLysozyme ${ }^{\mathrm{TM}}$ (MilliporeSigma, MA, USA; final

1053 concentration) and $0.5 \mathrm{U} / \mu \mathrm{l}$ Benzonase ${ }^{\circledR}$ Nuclease (MilliporeSigma, MA, USA, final

1054 concentration)). The amount of lysis buffer for each cell pellet was calculated as follows: $\mu$ l lysis

1055 buffer $=\mathrm{OD}_{600} \times \mathrm{ml}$ of culture pelleted $\times 60$. Cells were lysed for $30 \mathrm{~min}$ at $\mathrm{RT}$ in an overhead

1056 shaker. Next, lysed cells were mixed 1:5 in PBS (10.14 mM Na $2 \mathrm{HPO}_{4}, 1.76 \mathrm{mM} \mathrm{NaH}_{2} \mathrm{PO}_{4}, 2.7$

$1057 \mathrm{mM} \mathrm{KCl}, 137 \mathrm{mM} \mathrm{NaCl}$; $\mathrm{pH}$ 7.4, Boston Bioproducts, MA, USA) and then incubated in $1 \mathrm{x}$

1058 Laemmli SDS sample buffer (Boston Bioproducts, MA, USA) at $95^{\circ} \mathrm{C}$ for $10 \mathrm{~min} .10 \mu \mathrm{l}$ of the

1059 resulting solution was then applied to either $4-12 \%$ Criterion $^{\mathrm{TM}}$ XT Bis-Tris Protein Gels

1060 (BioRad, Hercules, CA, USA) or NuPAGE ${ }^{\text {тм }} 4$ - 12\% Bis-Tris Mini Protein Gels (Thermo Fisher

1061 Scientific, MA, USA). Upon gel separation, proteins were transferred to Amersham Protran 0.45

1062 NC nitrocellulose membranes (Cytiva, MA, USA) using a Trans-Blot Turbo Transfer System

1063 (BioRad Hercules, CA, USA), blocked in blocking buffer (TBST: $50 \mathrm{mM}$ Tris- $\mathrm{HCl}, 150 \mathrm{mM} \mathrm{NaCl}$,

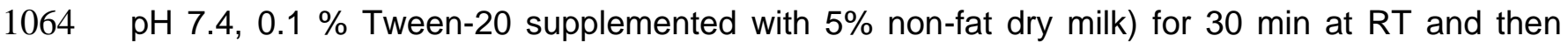

1065 incubated with mouse anti-a-NTD and rabbit anti-Cl primary antibodies (both 1:3,000 dil.) in

1066 blocking buffer for $1 \mathrm{~h}$ at RT. After washing with TBST, blots were incubated with IRDye®

1067 680RD goat anti-mouse and IRDye® $800 \mathrm{CW}$ goat anti-rabbit (both 1:10,000 dil.; LI-COR 
1068 Biosciences, NE, USA) in blocking buffer for $1 \mathrm{~h}$ at RT in the dark. After washing with TBST,

1069 proteins were then detected using a ChemiDoc MP system (BioRad. Hercules, CA, USA).

1070 Protein crystal structure analysis

1071 Interfaces of two protein complexes, SARS-CoV-2 Nsp16-Nsp10 (PDB ID: 6W4H [31]) and

1072 SARS-CoV-1 Nsp10-Nsp14 (PDB ID: 5NFY [29]), were analyzed using PDBePISA software

1073 (insert ref 20). Amino acids involved in hydrogen bond formation or substantially contributing to

1074 hydrophobic contacts in each complex were subjected to alanine mutagenesis and tested in

1075 B2H assays. Structural images were prepared using PyMOL software (Schrodinger, LLC. 2010.

1076 The PyMOL Molecular Graphics System, Version 2.4.1).

1077 Statistical analysis

1078 Presentation of bacterial two-hybrid data and statistical analysis using one-way or two-way

1079 ANOVA with Tukey's or Dunnett's multiple comparison test was done using GraphPad Prism (v.

1080 9.1.2; San Diego, CA, USA).

1081 


\begin{tabular}{|c|c|c|c|c|c|c|c|c|c|c|c|c|c|c|c|c|c|c|c|c|c|c|c|c|c|c|}
\hline & $\frac{\bar{a}}{z}$ & $\frac{N}{\text { O }}$ & $\frac{m}{2}$ & $\begin{array}{l}\frac{\mathrm{a}}{\mathrm{c}} \\
\frac{\mathrm{cos}}{z}\end{array}$ & $\begin{array}{l}\frac{10}{2} \\
\frac{0}{2}\end{array}$ & $\begin{array}{l}\infty \\
\frac{0}{2} \\
z\end{array}$ & $\frac{2}{z}$ & $\begin{array}{l}\infty \\
\text { an } \\
\text { w }\end{array}$ & $\begin{array}{l}\frac{\sigma}{\circ} \\
\frac{0}{Z}\end{array}$ & $\frac{\frac{0}{0}}{\frac{0}{2}}$ & $\frac{\frac{\pi}{0}}{\frac{0}{2}}$ & $\frac{\frac{N}{0}}{\frac{0}{2}}$ & $\frac{\frac{m}{0}}{\frac{\omega}{z}}$ & $\frac{\frac{v}{0}}{\frac{0}{2}}$ & $\frac{\frac{\pi}{0}}{\frac{\omega}{2}}$ & $\frac{\frac{\infty}{2}}{\frac{0}{2}}$ & లు & $\omega$ & $\mathbb{N}$ & 웅 & $\infty$ & $\stackrel{\circ}{\circ}$ & $\omega$ & $\Sigma$ & $z$ & ш \\
\hline Nsp1 & & & & & & & & & & & & & & & & & & & & & & & & & & \\
\hline Nsp2 & & & & & & & & & & & & & & & & & & & & & & & & & & \\
\hline Nsp3 & & & & & & & & & & & & & & & & & & & & & & & & & & \\
\hline Nsp4 & & & & & & & & & & & & & & & & & & & & & & & & & & \\
\hline Nsp5 & & & & & & & & & & & & & & & & & & & & & & & & & & \\
\hline Nsp6 & & & & & & & & & & & & & & & & & & & & & & & & & & \\
\hline Nsp7 & & & & & & & & & & & & & & & & & & & & & & & & & & \\
\hline Nsp8 & & & & & & & & & & & & & & & & & & & & & & & & & & \\
\hline Nsp9 & & & & & & & & & & & & & & & & & & & & & & & & & & \\
\hline Nsp10 & & & & & & & & & & & & & & & & & & & & & & & & & & \\
\hline Nsp11 & & & & & & & & & & & & & & & & & & & & & & & & & & \\
\hline Nsp12 & & & & & & & & & & & & & & & & & & & & & & & & & & \\
\hline Nsp13 & & & & & & & & & & & & & & & & & & & & & & & & & & \\
\hline Nsp14 & & & & & & & & & & & & & & & & & & & & & & & & & & \\
\hline Nsp15 & & & & & & & & & & & & & & & & & & & & & & & & & & \\
\hline Nsp16 & & & & & & & & & & & & & & & & & & & & & & & & & & \\
\hline $3 a$ & & & & & & & & & & & & & & & & & & & & & & & & & & \\
\hline 6 & & & & & & & & & & & & & & & & & & & & & & & & & & \\
\hline $7 a$ & & & & & & & & & & & & & & & & & & & & & & & & & & \\
\hline $7 b$ & & & & & & & & & & & & & & & & & & & & & & & & & & \\
\hline 8 & & & & & & & & & & & & & & & & & & & & & & & & & & \\
\hline 10 & & & & & & & & & & & & & & & & & & & & & & & & & & \\
\hline S & & & & & & & & & & & & & & & & & & & & & & & & & & \\
\hline M & & & & & & & & & & & & & & & & & & & & & & & & & & \\
\hline$N$ & & & & & & & & & & & & & & & & & & & & & & & & & & \\
\hline$E$ & & & & & & & & & & & & & & & & & & & & & & & & & & \\
\hline
\end{tabular}




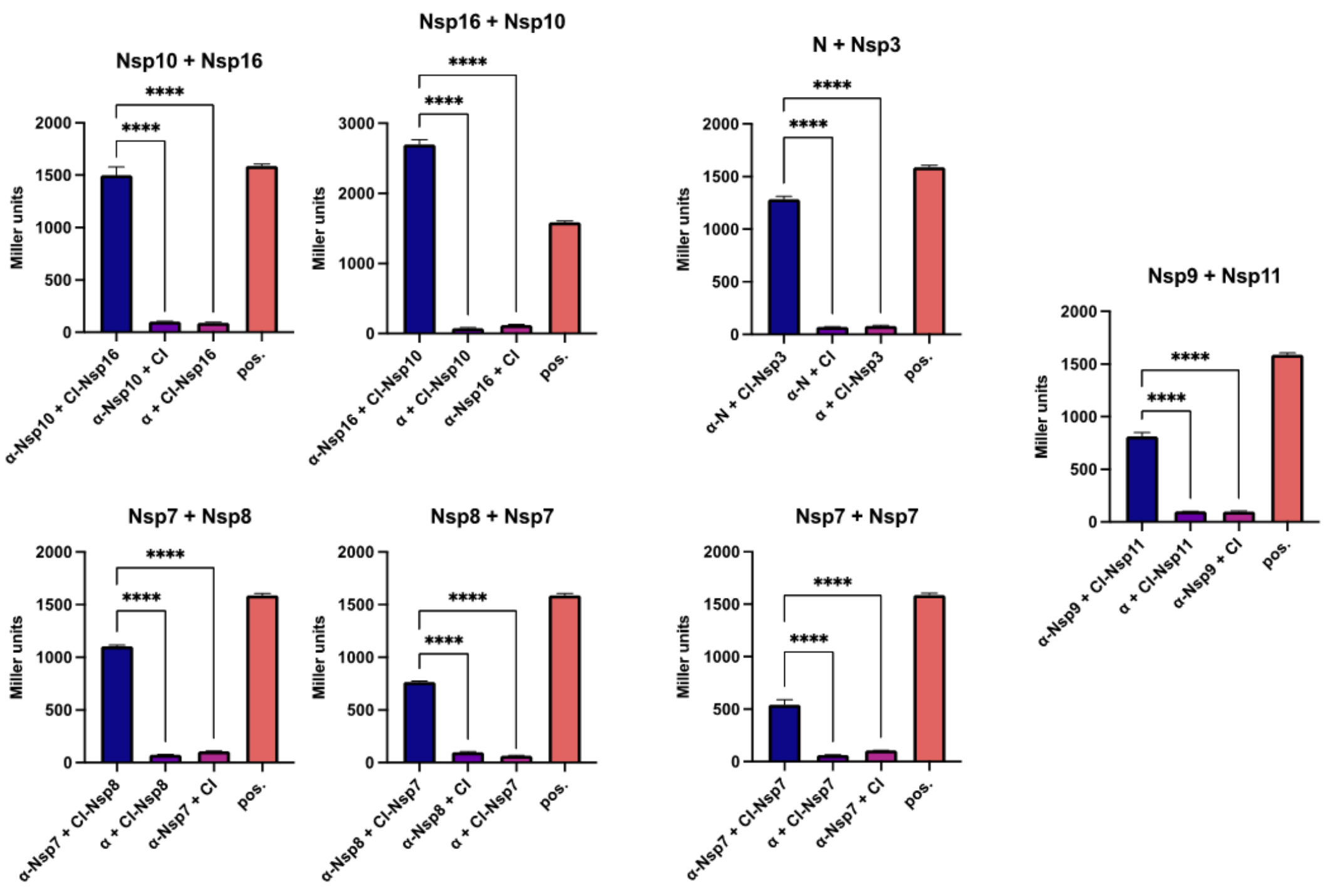


A

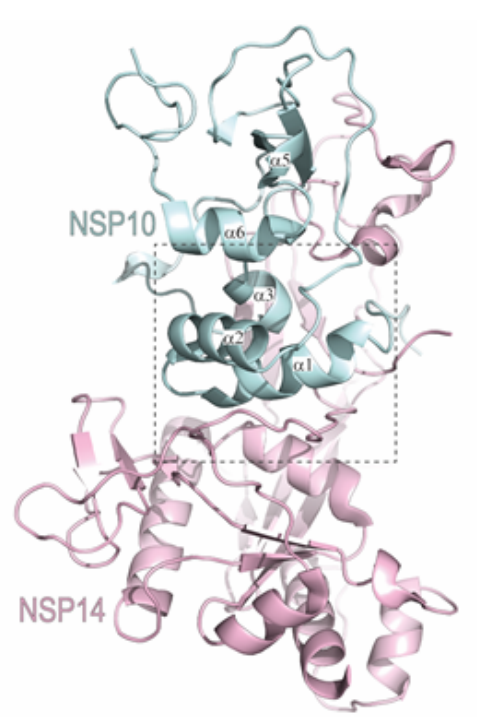

C

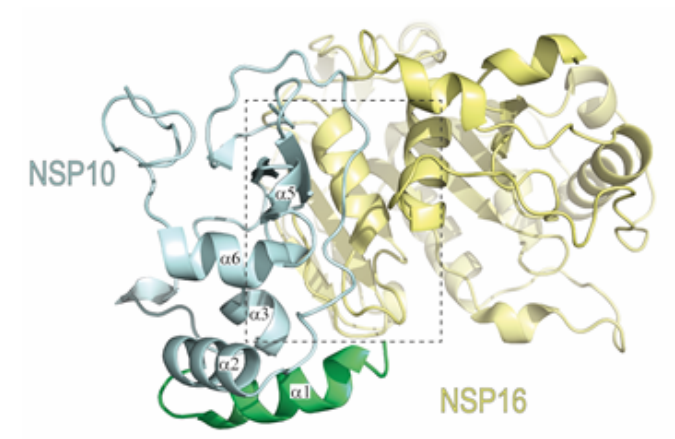

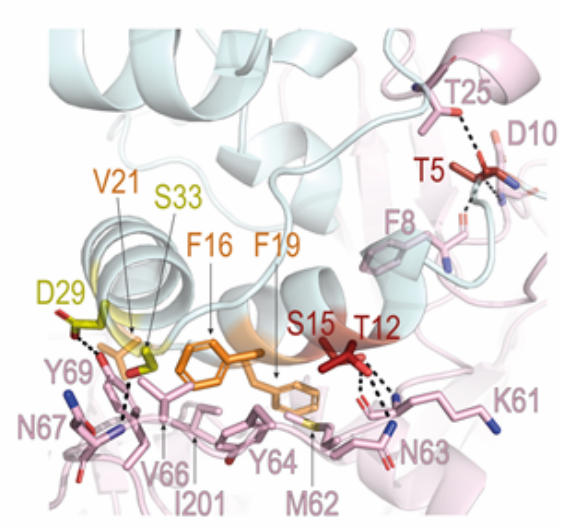

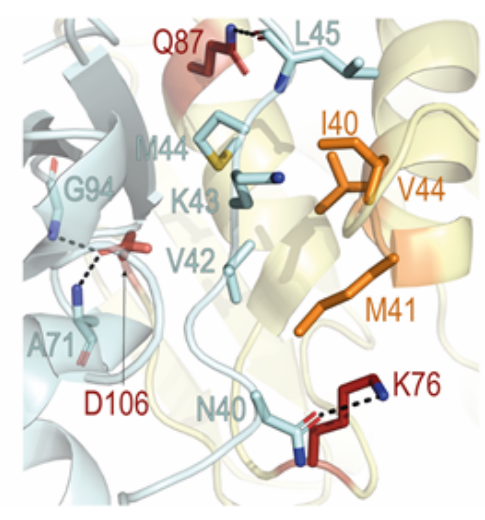

B

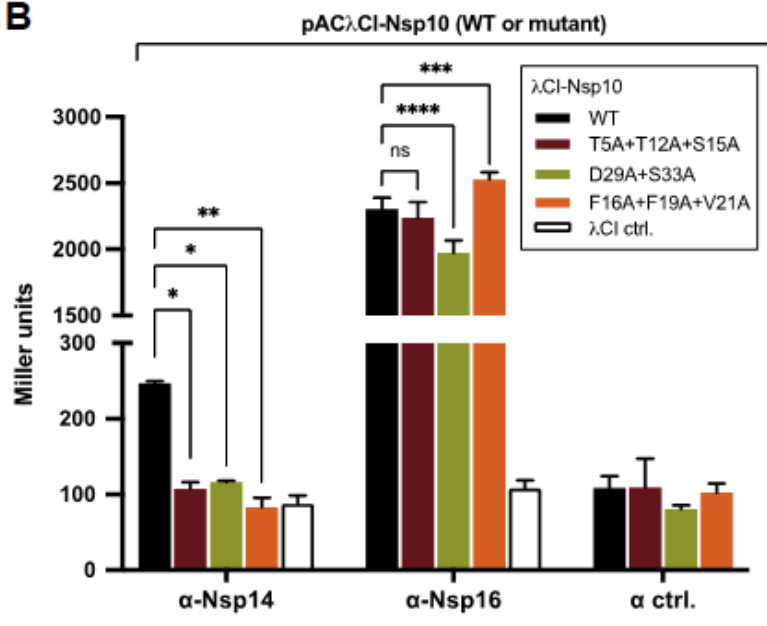

D

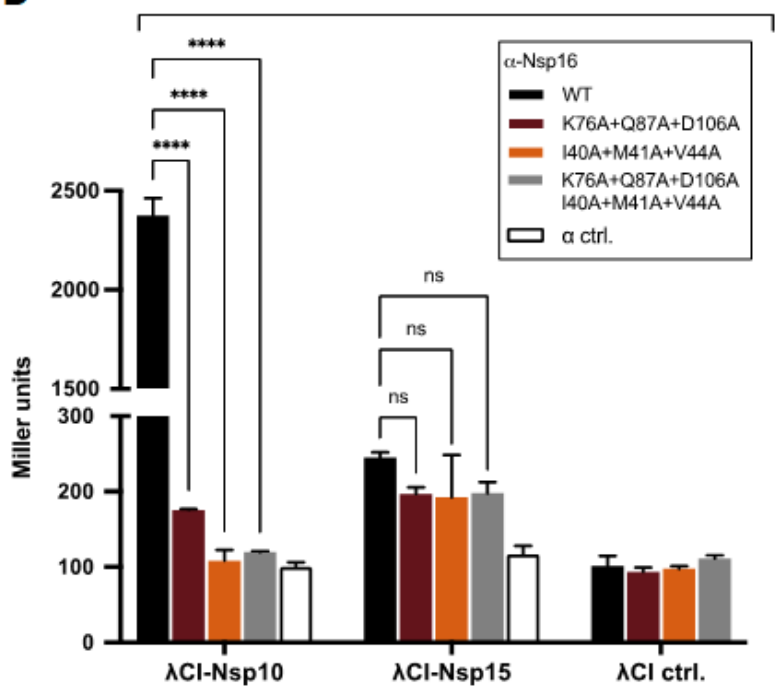


A

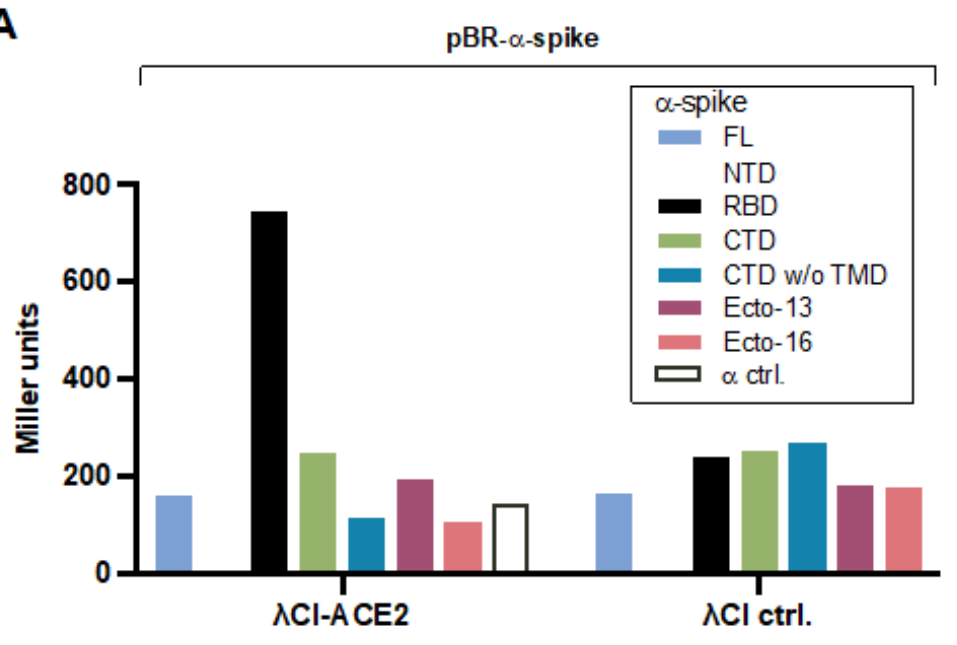

B

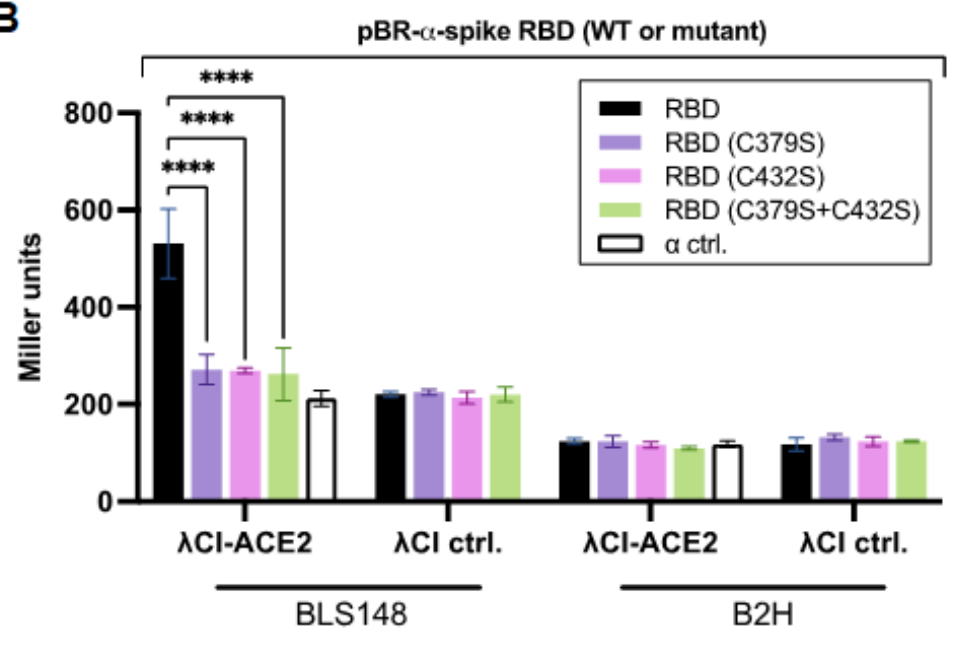

C

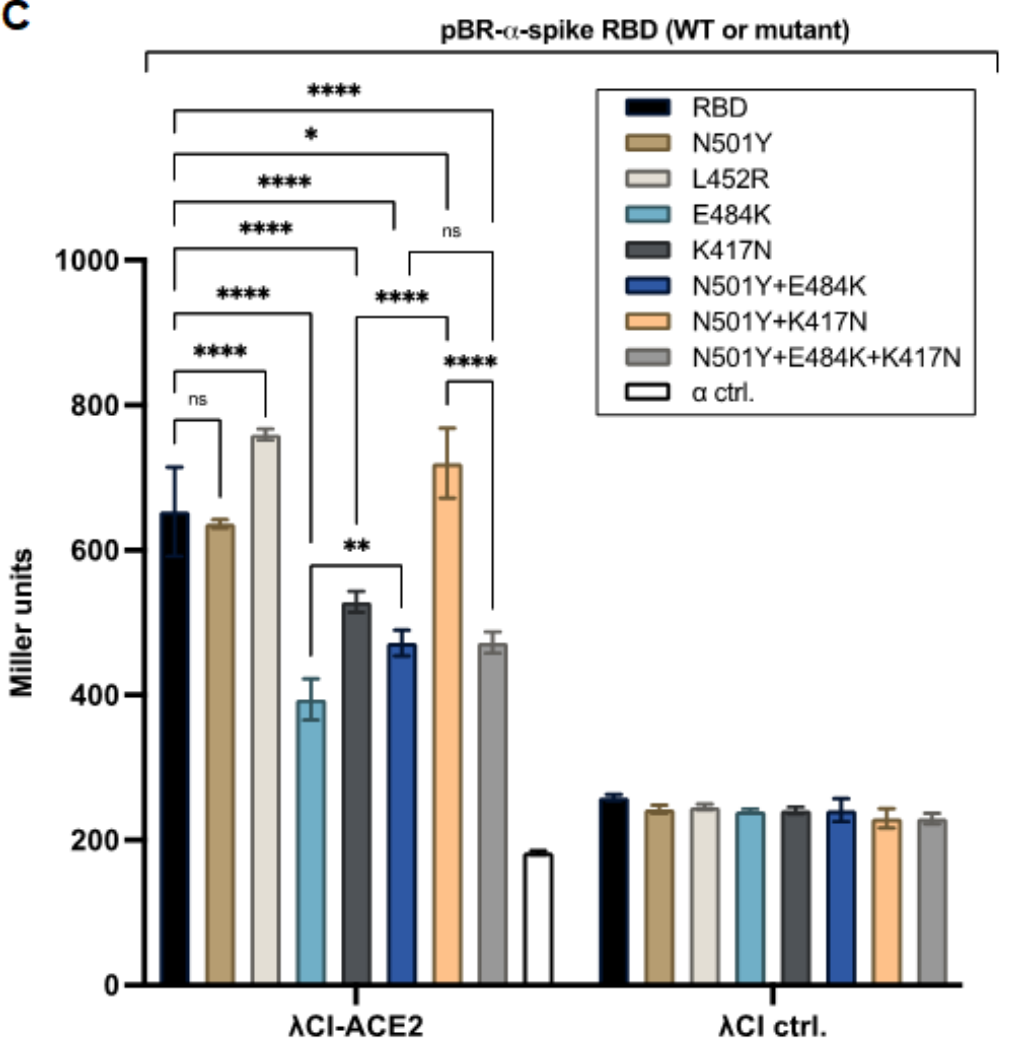

D

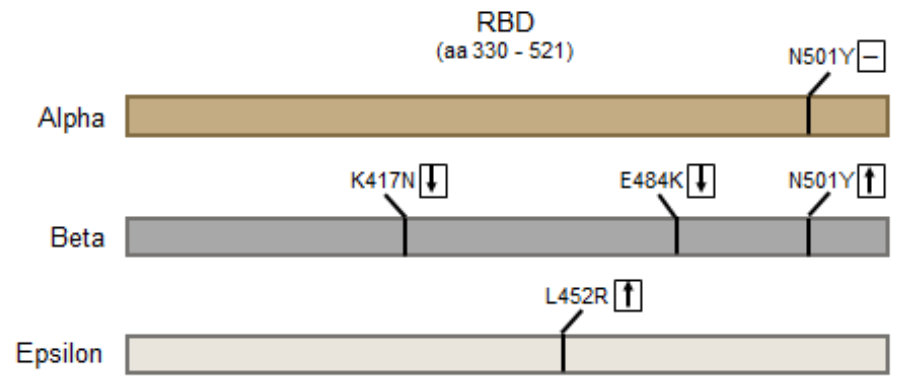

